\section{OPEN ACCESS}

Edited by:

Luigi Di Sarno,

University of Sannio, Italy

Reviewed by:

Alper llki,

Istanbul Technical University, Turkey

Constantinos Repapis,

University of West Attica, Greece

*Correspondence:

S. C. Chian

sc.chian@nus.edu.sg

Specialty section: This article was submitted to

Earthquake Engineering,

a section of the journal

Frontiers in Built Environment

Received: 09 February 2019

Accepted: 20 May 2019

Published: 18 June 2019

Citation:

Chian SC, Wilkinson SM, Whittle JK, Mulyani R, Alarcon JE, Pomonis A,

Saito K, Fraser S, Goda K,

Macabuag J, Offord $M$, Hunt-Raby AC, Sammonds $P$,

Franco G, Stone H, Ahmed B,

Hughes FE, Jirouskova NK, Kaminski S and Lopez J (2019)

Lessons Learnt From the 2009

Padang Indonesia, 2011 Tōhoku

Japan and 2016 Muisne Ecuador

Earthquakes.

Front. Built Environ. 5:73.

doi: 10.3389/fbuil.2019.00073

\title{
Lessons Learnt From the 2009 Padang Indonesia, 2011 Tōhoku Japan and 2016 Muisne Ecuador Earthquakes
}

\author{
S. C. Chian ${ }^{1 *}$, S. M. Wilkinson ${ }^{2}$, J. K. Whittle ${ }^{3}$, R. Mulyani ${ }^{4}$, J. E. Alarcon ${ }^{5}$, A. Pomonis ${ }^{6}$, \\ K. Saito ${ }^{6}$, S. Fraser ${ }^{7}$, K. Goda ${ }^{8}$, J. Macabuag ${ }^{9}$, M. Offord ${ }^{10}$, A. C. Hunt-Raby ${ }^{11}$, \\ P. Sammonds ${ }^{12}$, G. Franco ${ }^{13}$, H. Stone ${ }^{9}$, B. Ahmed ${ }^{12}$, F. E. Hughes ${ }^{14}$, N. K. Jirouskova ${ }^{15}$, \\ S. Kaminski ${ }^{16}$ and J. Lopez ${ }^{16}$
}

${ }^{1}$ Department of Civil and Environmental Engineering, National University of Singapore, Singapore, Singapore, ${ }^{2}$ School of Engineering, Newcastle University, Newcastle upon Tyne, United Kingdom, ${ }^{3}$ Magnusson Klemencic Associates, Seattle, WA, United States, ${ }^{4}$ Department of Civil and Structural Engineering, Universitas Bung Hatta, West Sumatra, Indonesia, ${ }^{5}$ Willis Re, London, United Kingdom, ${ }^{6}$ Cambridge Architectural Research, Ltd., Cambridge, United Kingdom, ${ }^{7}$ Fraster Disaster Risk Consulting, Brighton, United Kingdom, ${ }^{8}$ Department of Earth Sciences, Western University, London, ON, Canada, ${ }^{9}$ EPICentre, University College London, London, United Kingdom, ${ }^{10}$ Sellafield Sites, Cumbria, United Kingdom, ${ }^{11}$ School of Engineering, University of Plymouth, Plymouth, United Kingdom, ${ }^{12}$ Institute for Risk and Disaster Reduction, University College London, London, United Kingdom, ${ }^{13}$ Guy Carpenter, Dubin, Ireland, ${ }^{14}$ Department of Engineering, University of Cambridge, Cambridge, United Kingdom, ${ }^{15}$ Department of Civil and Environmental Engineering, Imperial College London, London, United Kingdom, ${ }^{16}$ Arup London, London, United Kingdom

This paper presents the observations during the UK Earthquake Engineering Field Investigation Team (EEFIT)'s post-earthquake reconnaissance missions to the September 20, 2009 Padang ( $\left.M_{w} 7.6\right)$, March 11, 2011 Tōhoku (M $\left.M_{w} 9.0\right)$ and April 16, 2016 Muisne $\left(M_{w} 7.8\right)$ earthquakes. The performance of buildings and geotechnical structures within the affected regions were investigated to gain insights on their design and construction deficiencies. Findings on these damages observed are compared along with the characteristics of the earthquake and nature of building codes in these countries. They include building damages attributed to a combination of structural resonance, deficiencies in reinforcement detailing, vulnerability to soft story collapse, ground settlement, soil liquefaction, and landslides. It was demonstrated that buildings which were severely damaged had natural building frequencies coinciding with the dominant frequencies of the ground shaking. The locations of damage of several such buildings showed insufficient confining reinforcements and lapping of stirrup links. Soft story collapses were also observed in the three earthquakes, although many were attributed to old building codes that were less effective. In areas affected by the Muisne earthquake, soft story collapses were mainly found at mid height of the building rather than at the ground floor as observed in the Padang and Tōhoku earthquakes, likely due to extension of building long after the bottom floors were completed. Such extension of building can either lead to local reduction in capacity due to weaker concrete-rebar bonding, possibly insufficient lapping of reinforcement, as well as increased axial loads. In the aspect of geotechnical failure, foundations of buildings found on piles performed reasonably well, except for areas affected by soil liquefaction. Landslides occurred following these earthquakes led to large concentration of casualties and property losses, 
motivating the EEFIT teams to invest efforts in hazard mapping and ground-truthing exercises using satellite images at Padang and Muisne earthquakes respectively. Such geospatial tools applied in these three earthquakes were reviewed and demonstrated to be capable of identifying landslide sites and producing reliable landslide hazard map.

Keywords: earthquakes, Padang, Tōhoku, Muisne, buildings, foundations, landslides, geospatial tools

\section{INTRODUCTION}

The UK-based Earthquake Engineering Field Investigation Team (EEFIT) has been deploying multi-disciplinary teams following major earthquakes in the world and reporting their findings to the engineering community since 1982 . Key activities undertaken by the teams during these reconnaissance include the assessment of performance of buildings and infrastructure, as well as their consequent effects on local communities. In this paper, the effects of three catastrophic earthquakes that struck Indonesia, Japan and Ecuador between 2009 and 2016 are reviewed. The objective is to investigate the similarities and differences in typical structural and geotechnical damage observed with differing earthquake characteristics, geological settings, building typologies and engineering practices. Such investigations are vital in better understanding vulnerability of building stocks and shortcomings of seismic design of buildings, so that existing buildings can be better retrofitted and building codes revised accordingly if necessary. It should be noted that these missions were conducted over a month after the earthquake so as not to impede search and rescue operations. Therefore many of the severely affected buildings and geotechnical failures may have already been removed.

The 2009 earthquake $\left(M_{\mathrm{w}} 7.6\right)$ was centered near Padang, Indonesia the largest city of western Sumatra. Tremors were felt as far as Singapore $460 \mathrm{~km}$ away. The earthquake caused the loss of 1,117 lives of which 321 were related to landslides. In 2011, a megathrust earthquake measuring $M_{w} 9.0$ occurred off the east coast of Japan, triggered a powerful tsunami which resulted in a total of 15,852 fatalities. In 2016, the Pacific coast of Ecuador was shaken by an $\mathrm{M}_{\mathrm{w}} 7.8$ earthquake at Muisne with coastal towns suffering extensive damage to buildings sited on young Quaternary sediment deposits, causing the loss of 668 lives.

\section{THE 2009 PADANG EARTHQUAKE}

In the evening of 30th September 2009, a major earthquake registering a magnitude $M_{w} 7.6$ occurred off the coast of Padang in West Sumatra, followed by an inland earthquake measuring $M_{W} 6.6$ the next day morning. The main shock was triggered by oblique-thrust faulting near a long undersea subduction fault interface between the Australian and Sunda Plates, while the inland earthquake that followed occurred due to a dextral (rightlateral) strike-slip movement at the proximal Great Sumatran Fault [United States Geological Survey (USGS), 2010a,b]. The United States Geological Survey (USGS) estimated the focus of the $M_{w} 7.6$ earthquake to be located at a depth of $81 \mathrm{~km}$ and a distance of $60 \mathrm{~km}$ west northwest of the city of Padang (city population of around 785,000 at the time of event). A tsunami warning was issued but later withdrawn. Significant damage to buildings due to ground shaking and large-scale lethal landslides occurred.

Damage to buildings and human casualties in each affected district are shown in Figure 1A. The distribution of the damage agreed with the degrees of shaking estimated based on the Modified Mercalli Intensity (MMI) by the USGS, with populous districts near the coast suffering the heaviest damage. These low-lying coastal areas and settlements are located on young alluvium sediment (Figure 1B) are expected to amplify shaking, considerably leading to higher damage to infrastructure. In the uplands, steep slopes and weathered Quaternary volcanic sediments are highly prone to landslides in periods of heavy rainfall or under seismic shaking.

The EEFIT reconnaissance mission (7th to 13th November 2009) covered most of Padang city (Kota Padang). The outskirt districts of Pariaman town (Kota Pariaman) were also visited, where more than 300 fatalities were reported in landslide-affected areas. The survey covered slightly more than a half of the densely populated regions of Padang and Pariaman, extending a total area of approximately $245 \mathrm{~km}^{2}$, in which $125 \mathrm{~km}^{2}$ were in Padang, and $120 \mathrm{~km}^{2}$ in Pariaman. More than 200 buildings were surveyed in Padang and approximately 60 village buildings in Pariaman [Earthquake Engineering Field Investigation Team (EEFIT), 2009; Chian et al., 2010].

\section{THE 2011 TŌHOKU EARTHQUAKE}

On 11th March, 2011, an $M_{w} 9.0$ earthquake occurred off the coast of Tōhoku in north-east of Honshu, Japan at the Japan Trench where the lithosphere of the Pacific Plate subducts under the Okhotsk Plate. The rupture of the lithosphere was about $500 \mathrm{~km}$ long and $200 \mathrm{~km}$ wide (Ammon et al., 2011). Ground shaking was felt as far as western Japan and lasted for almost $4 \mathrm{~min}$ (220 s). The mainshock and aftershocks (particularly the $M_{w} 7.1$ event on 7th April 2011) caused severe damage to buildings and infrastructure, such as ports, bridges, railways, roads, the Sendai airport, electricity, sewerage and water supply network across many prefectures in the Tōhoku coastal region.

The earthquake triggered a large tsunami along the Tōhoku coast as indicated in Figure 2 [Japan Meteorological Agency (JMA), 2013], which damaged hundreds of kilometers of sea defenses and more than 900,000 buildings in Iwate, Miyagi, Fukushima and Ibaraki Prefectures (Ministry of Land Infrastructure Transport and Tourism, 2011). More than 129,000 buildings were completely destroyed and 264,000 partially 

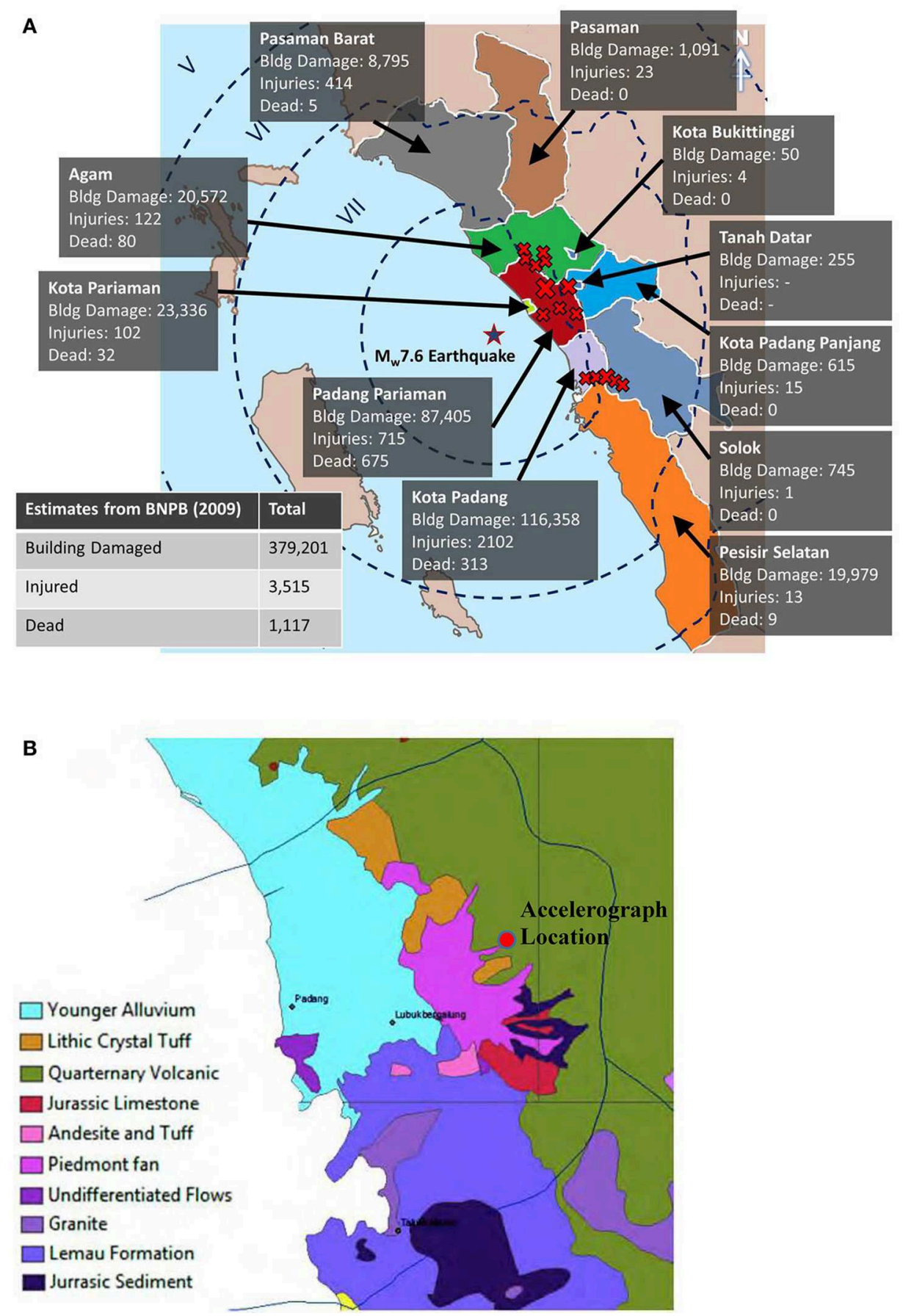

FIGURE 1 | Location and geological map of Padang. (A) Distribution of losses and MMI scale felt in the district of Padang [after Badan Nasional Penanggulangan Bencana (BNPB), 2009; United States Geological Survey (USGS), 2010a]. (B) Geological map of Padang (ESDM, 2009).

destroyed by the tsunami. In contrast, the earthquake shaking affected only 95,000 buildings (National Police Agency of Japan, 2012). The large incidents of road damage, tilted houses and uplift of manholes in Chiba Prefecture were attributed to the widespread soil liquefaction in Urayasu City. The Japan National Police Agency estimated 15,852 deaths, 6,011 injured and 3,287 people missing due to the earthquake and tsunami, including around 790 earthquakerelated deaths (National Police Agency of Japan, 2012). This was the largest earthquake recorded in Japan since the beginning of instrumental seismology in the 1900s, and the world's most costly, with total direct loss due to earthquake and tsunami estimated to be around $¥ 23$ trillion (US\$297bn) (Government of Japan, 2011). 


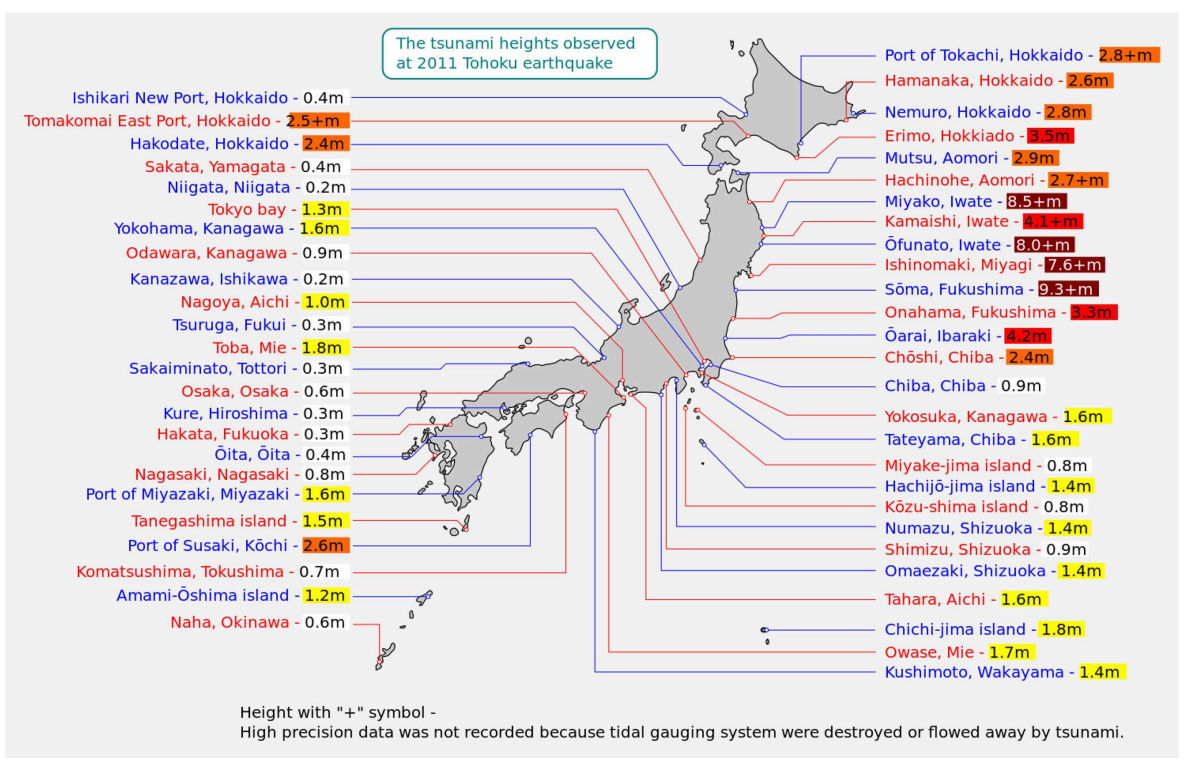

FIGURE 2 | Tsunami affected locations along the east coast of Japan [Japan Meteorological Agency (JMA), 2013].

Japan is exposed to some of the world's most extreme natural hazards and is one of the most prepared countries in terms of earthquake and tsunami. Early warning systems for earthquakes and tsunami were in place, sea defenses constructed along coastlines, frequent evacuation drills conducted in these coastal communities and strict seismic building codes have been implemented. However, an earthquake and tsunami of such magnitude was not expected. Considering the significance of the event, a multidisciplinary EEFIT team of 9 was sent to conduct an initial field mission (27th May to 4th June 2011) with a focus on assessing damage to buildings and coastal infrastructure [Earthquake Engineering Field Investigation Team (EEFIT), 2011]. A subsequent mission to assess recovery and reconstruction was conducted from 1st to 7 th June 2013 [Earthquake Engineering Field Investigation Team (EEFIT), 2013].

\section{THE 2016 MUISNE EARTHQUAKE}

A megathrust earthquake measuring $\mathrm{M}_{\mathrm{w}} 7.8$ shook Ecuador's Pacific Coast on the evening of 16th April 2016. The hypocentre of the earthquake was located approximately $29 \mathrm{~km}$ SSE of Muisne, and $168 \mathrm{~km}$ from the country's capital Quito. The earthquake occurred at the interface where the Nazca Plate subducts eastward beneath the South American Plate at a rate of about $61 \mathrm{~mm} /$ year [United States Geological Survey (USGS), 2016] and a dipping angle of about $16^{\circ}$ (Parra et al., 2016). Much of the observed damage due to this event extends south along the coast from the hypocentre in the Manabi region. Coastal towns, particularly Pedernales, Canoa, Bahia de Caraquez and Manta in Figure 3A [United States Geological Survey (USGS), 2016] suffered extensive damage. The peak ground accelerations recorded at strong motion stations by the Instituto Geofisico ranged from $0.51 \mathrm{~g}$ in Portoviejo to $1.55 \mathrm{~g}$ in Pedernales. Several of these towns are sited on young Quaternary sediment deposits as evident in Figure 3B (Dirección de Geologiì a y Minas (DGGM), 1982). A total of 668 were killed and 6,274 people severely injured (International Federation of Red Cross Red Crescent Societies, 2016), making it the worst disaster in Ecuador since the 1949 Ambato earthquake.

Ecuador has a history of large seismic events exceeding $M_{w}$ 7.0. The epicenter of the 2016 earthquake was located at the southern end of the $400-500 \mathrm{~km}$ long rupture area of the 1906 $\mathrm{M}_{\mathrm{W}} 8.8$ event which generated a tsunami that killed hundreds of people [United States Geological Survey (USGS), 2016]. Closer to the 2016 epicenter, an $\mathrm{M}_{\mathrm{W}} 7.8$ earthquake occurred in 1942, and an $M_{W} 7.2$ event occurred in 1998 near Bahia de Caraquez.

Between 24th May and 7th June 2016, the team was deployed in the Manabi region, primarily in coastal areas and for 1 day investigating major damage inland. As with earlier event, the team surveyed structural damage to buildings and infrastructure but additionally undertook geotechnical investigations with geophysical methods, obtained aerial photography with drones, validated satellite-derived landslide data, and interviewed affected communities [Earthquake Engineering Field Investigation Team (EEFIT), 2016; Franco et al., 2017]. A total of 1,332 buildings were assessed in areas including Manta, Portoviejo, Bahía de Caráquez, Jama, and Pedernales. Surveys of buildings around existing strong motion recording stations were also carried out to correlate damage to ground motion. In Manta and Portoviejo, a high concentration of damage to buildings was observed, particularly at Tarqui and the central business district. 


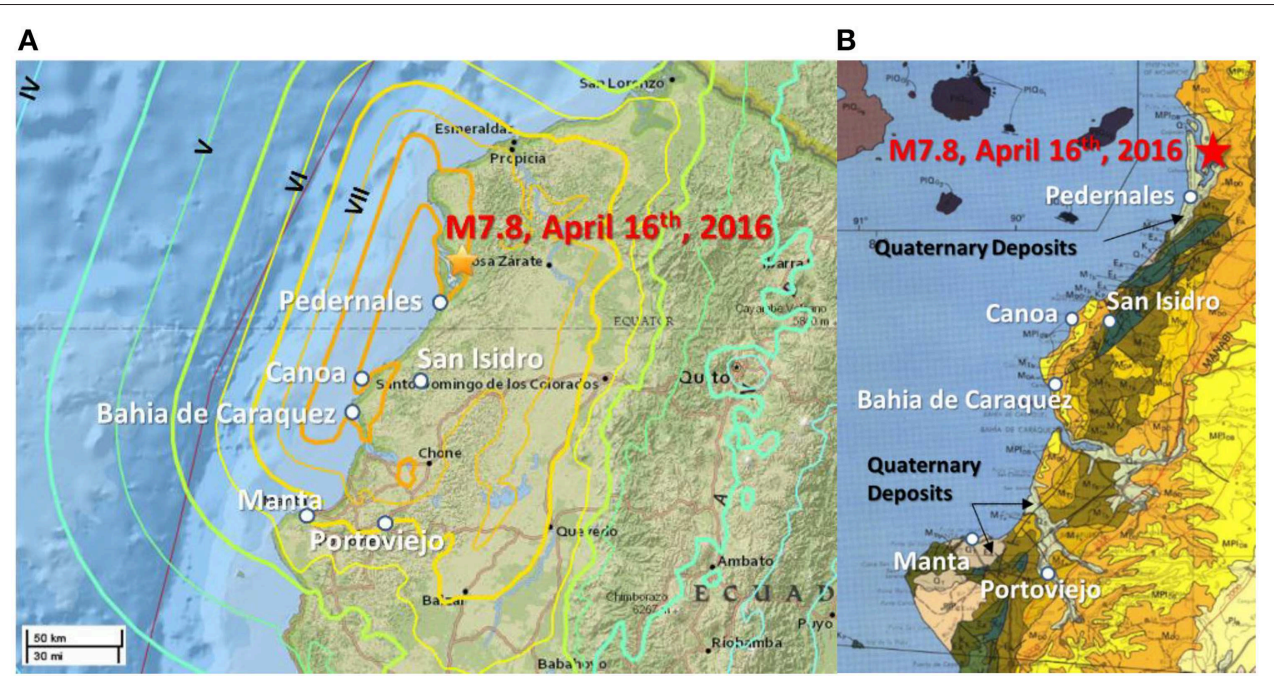

FIGURE 3 | Location and geological map of affected regions in Ecuador. (A) USGS Shake Map Intensities [United States Geological Survey (USGS), 2016]. (B) Geological map extract [after Dirección de Geologil a y Minas (DGGM), 1982].

\section{STRUCTURAL DAMAGE TO BUILDINGS}

This section discusses the building typologies and observed damage in the affected regions of the three earthquakes. Similarities and differences in building failures are evaluated in correspondence to local building codes and engineering practices. Lastly, a summary of findings is provided at the end of the section.

\section{THE 2009 PADANG EARTHQUAKE}

At Padang in Indonesia, the structures in Padang were primarily masonry structures (both confined and unreinforced) and RC frames with masonry infill. A vast majority of the buildings in Padang were one- or two-story residential and two- to threestory commercial structures due to planning regulations limiting building heights to 6 stories prior to the relocation of the airport in 2005. Only a few steel buildings were observed in the city. A majority of small structures were very poorly constructed with low quality building materials. Of the more recent and larger engineered structures the quality of construction was reasonable, with occasional poor quality observed. During the field survey, very large spacing between confining links, particularly at the beam/column connections and joints, was commonly observed in collapsed RC buildings. The use of smooth bars for links and main reinforcement instead of ribbed bars was another common feature observed in collapsed buildings (Figure 4A). Soft-story collapse was observed to be the major contributor to the collapse of major engineered structures (e.g., Figure 4B). Of the engineered structures, government buildings and hotels seemed to be particularly affected. Unreinforced masonry infill panels performed poorly with extensive cracking. Buildings over three stories seemed to be the most affected. Although these types of buildings would have been engineered, they performed worse than simple, poorly constructed buildings in the affected city area.
This could be due to the depth of the earthquake where these layers of soil would have filtered off high frequency components of the earthquake. During the earthquake, BMKG recorded a maximum peak ground acceleration of $0.3 \mathrm{~g}$, which lasted about $20 \mathrm{~s}$. Considering that the acceleration record was taken from a location with relatively stiff soil according to geological map (ESDM, 2009) in Figure 1B, the earthquake ground shaking would have been amplified at Padang city. Padang City lies on relatively thick alluvium deposits as shown in the same figure. As a result, it was estimated that the earthquake produced PGAs around $0.4-0.6 \mathrm{~g}$ across Padang City [Earthquake Engineering Field Investigation Team (EEFIT), 2009].

Based on the synthetic earthquake time history in Figure 5A, dominant frequencies were between 2 and $5 \mathrm{~Hz}$. This range of frequencies are more likely to affect two- to five- stories building with coinciding natural frequencies, which were in agreement with observations that RC buildings six stories and above did not suffer significant structural damage, including one with glass façade. In contrast, schools were usually simple one-story masonry structures with timber and corrugated steel roofs. They performed particularly badly with 2,164 severely damaged or experienced collapse [Badan Nasional Penanggulangan Bencana (BNPB), 2009]. Industrial and port facilities performed extremely well and only suffered minor structural damage. There were examples of buildings that experienced strong ground shaking as evident by the major damage to masonry infill, but suffered only minimal structural damage. This suggests that the latest Indonesian earthquake code, its design practice and construction, is seismically sufficient for an earthquake of this intensity. The first Indonesian national building code (PPIUG) was developed in 1983 (Direktorat Penyelidikan Masalah Bangunan, 1983). It was adapted from the New Zealand seismic standard which applied uniform hazard concept with 200 years design earthquake return period. This Indonesian code had been revised several times since then, however, it is only since 2002 that 

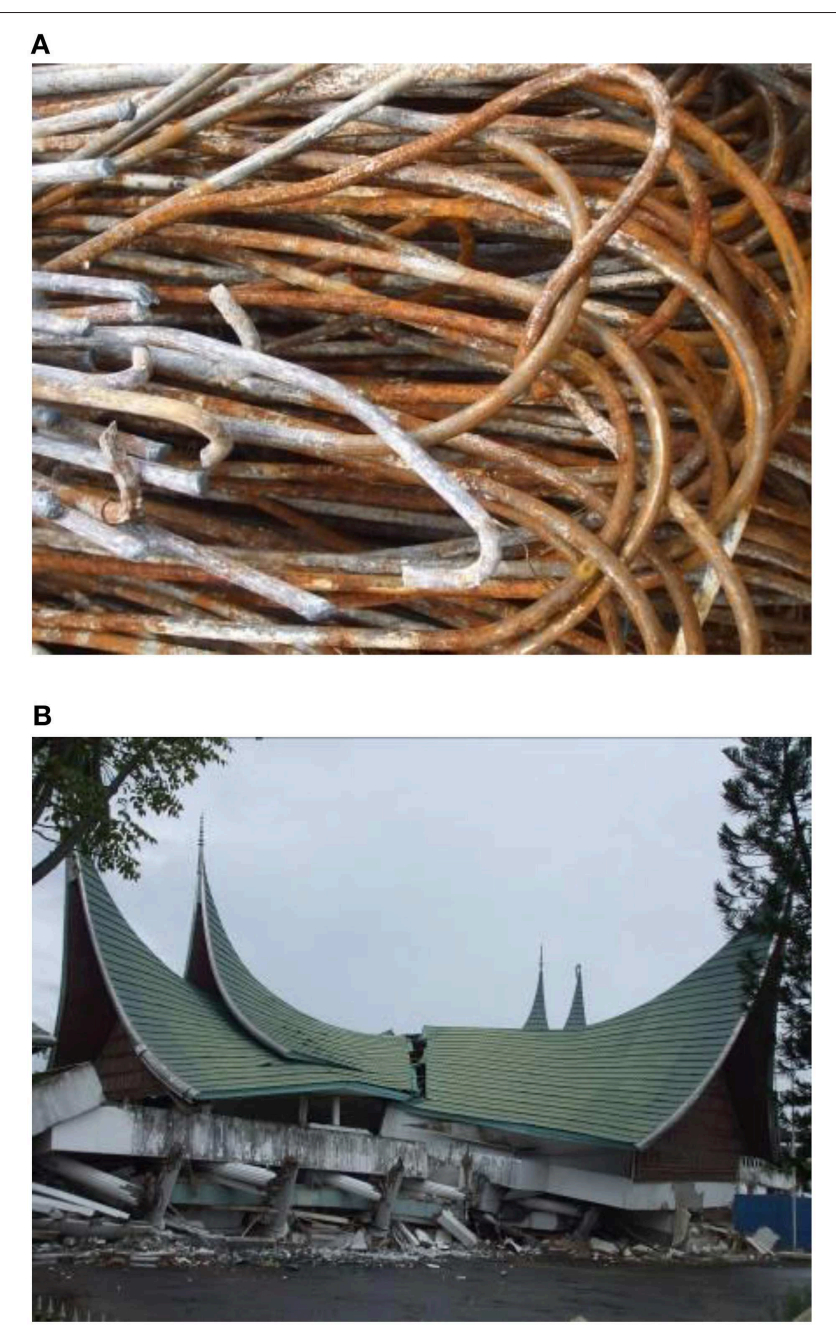

FIGURE 4 | Deficiency in reinforcement and typical collapse mode. (A) Smooth plain bars used as main reinforcements (found in a collapsed shophouse) at Padang city. (B) Soft story collapse of the Public Works building at Padang city.

engineered structures were obliged to meet the requirements of the national seismic code (Standar Nasional Indonesia, 2002: SNI-1726:2002), which can be described as a modern code similar to the American (Uniform Building Code, 1997). This may explain the seemingly inadequate design and construction of buildings prior to the compulsory implementation of the code in 2002. Larger engineered buildings in Pariaman, although much closer to the epicenter, seemed to fare better than those in Padang (Wilkinson et al., 2012).

\section{THE 2011 TŌHOKU EARTHQUAKE}

In the north-eastern region of Honshu, the main island of Japan, residential houses in Japan were predominantly timberframe structures for single-family houses (accounting for about $60 \%$ of visited structures) and steel-frame or RC construction for multi-family buildings (making up the remaining 40\%).
Commercial and industrial buildings were commonly steel-frame or variations of composite steel and RC construction. Given the history of amendments to the building code, older structures were generally less seismically resistant as compared to modern structures. With respect to building codes, Japan has one of the most advanced building codes since the 1981 implementation, incorporating experience from the 1978 Miyagi-Oki earthquake, which introduced the two-level approach (serviceability and ultimate limit states) and stricter requirements for tall buildings. The latest amendments to the code were in 2000, where seismic performance requirements and verification based on earthquake response spectra at bedrock with soil amplification factors were specified after the inclusion of experiences from severe earthquakes, such as the 1995 Kobe earthquake (Midorikawa et al., 2004). As a result of the continuous improvement in building regulations, the majority of the buildings in the Tohoku region suffered minimal damage from the earthquake shaking. This was partly due to the frequency content of the shaking which was dominant between 3 and $10 \mathrm{~Hz}$, as shown in Figure 5B. This range of frequencies were far from typical building natural frequencies. There was however some cases of severely damage buildings. Damage to wooden structures was observed in Sendai, Sukagawa and Shirakawa, which indicated the susceptibility of wooden structures against strong earthquake shaking in these areas (Goda et al., 2012). For RC buildings, diagonal shear cracks and column buckling failures were observed in some buildings which were identified as unsafe with red-label notices by the local authorities. Observations of some RC residential apartments used insufficient hook length and angles. Ground settlement of about 100 to $200 \mathrm{~mm}$ could also have exacerbated the severity of damage. Other RC buildings such as the Sukagawa city office, constructed in 1970, showed similar failures (see Figure 6A). The buckling and shear failure of columns were also largely due to the construction adhering to an older version of the code during construction, with emphasis placed on providing more reinforcements at the joints at that time. As a result, failures occurred toward the middle of the column where there was less provision of reinforcement. In contrast to the frequent observations of soft-story failures in many reconnaissance missions such as the 2009 Padang earthquake, soft-story collapse was rarely observed in this Tōhoku earthquake event. An exception was an office building in Sendai constructed in 1969 (Figure 6B), where columns failed by shear due to insufficient confining reinforcement stirrups. The major contributor to the number of damaged buildings in this event was tsunami forces on structures near the coast. Buildings were observed to have damage to cladding, openings and internal elements, due to the tsunami force and impact from floating debris (including road vehicles, boats, machinery, other dislodged structures, and trees). In several areas, structures had been burned by fire from flammable material and liquids floating on the water surface. Typical damage to cladding is shown in Figure 6C, but steel structures were commonly bent by debris impact. RC buildings with stiff shear walls did not allow rapid tsunami flow through the buildings, and in several instances buildings with small plan layout suffered from sheared piles and overturning due to extreme tsunami flow (Figure 6D). 
A

Absolute Acceleration Spectrum (Stiff Soil, 5\% Damping)

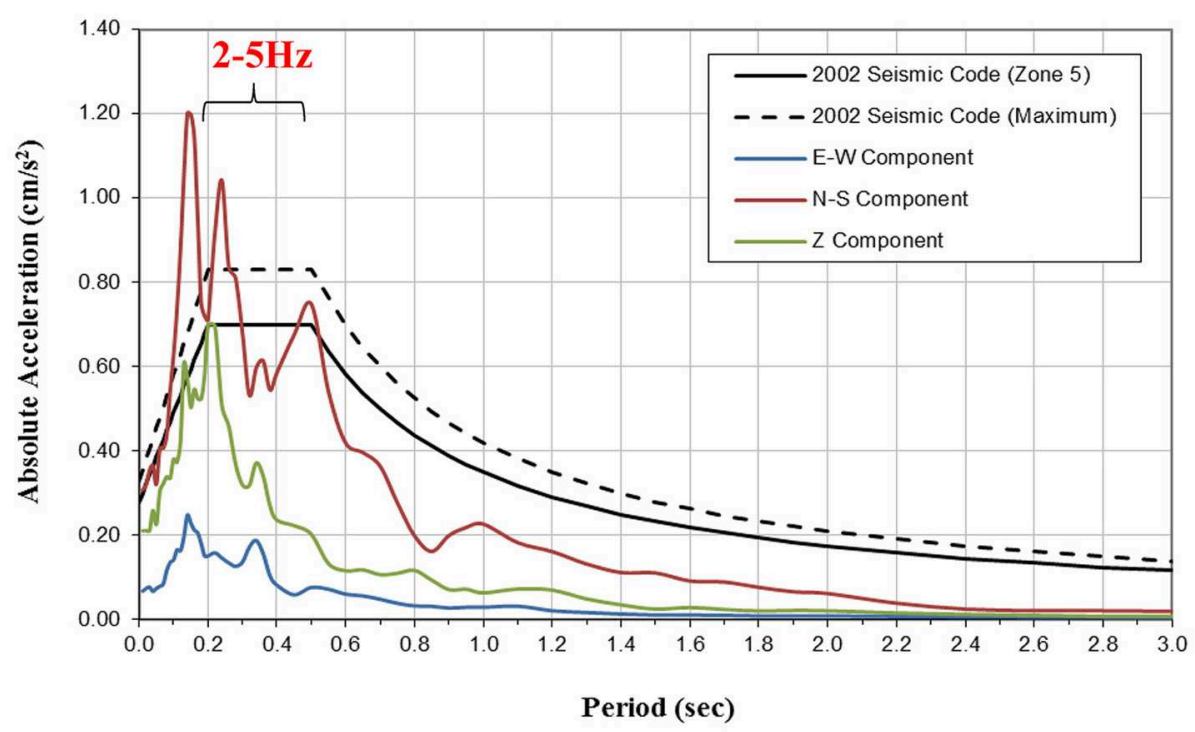

B

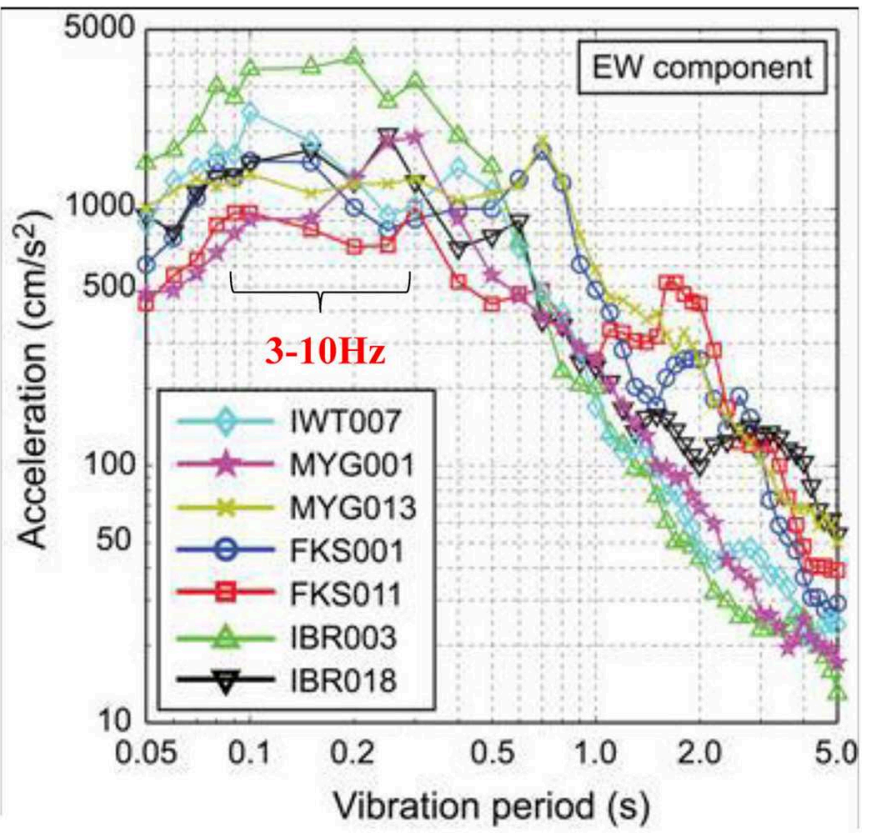

FIGURE 5 | Response spectra of Padang and Tohoku earthquakes. (A) 2009 Padang earthquake response spectra vs. uniform hazard response spectra of Indonesian seismic code [Earthquake Engineering Field Investigation Team (EEFIT), 2009]. (B) Elastic response spectra of the recorded mainshock gorund motions, East-West component at the seven K-NET station [Earthquake Engineering Field Investigation Team (EEFIT), 2011].

\section{THE 2016 MUISNE EARTHQUAKE}

In Ecuador, the majority of the surveyed buildings were RC frame structures with block or brick masonry infill ( $\sim 72 \%)$. These types of buildings experienced greater levels of damage than buildings that incorporated timber and/or bamboo into the structure, including quincha and bahareque (Kaminski, 2013), which were the second most prevalent in the region $(\sim 23 \%)$. Steel and unreinforced masonry were observed but were few in number constructed $(\sim 5 \%)$. Key structures, such as churches, public facilities, hospitals, and high-rise apartment blocks were also assessed. Inadequate design and detailing of RC moment frames were observed. The masonry used to infill frames in facades and partition walls was inadequate in both design and detailing, as 


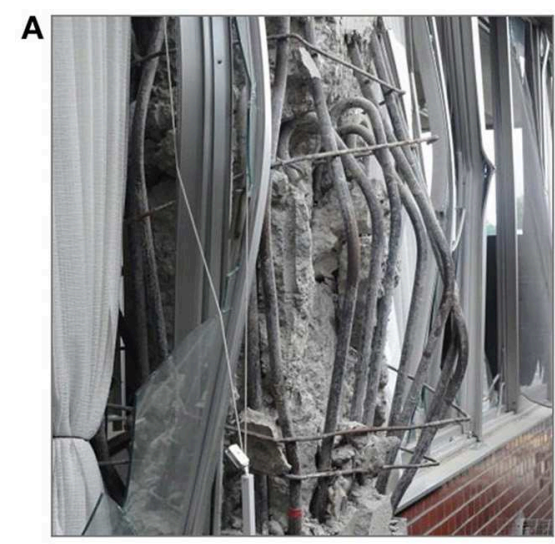

C

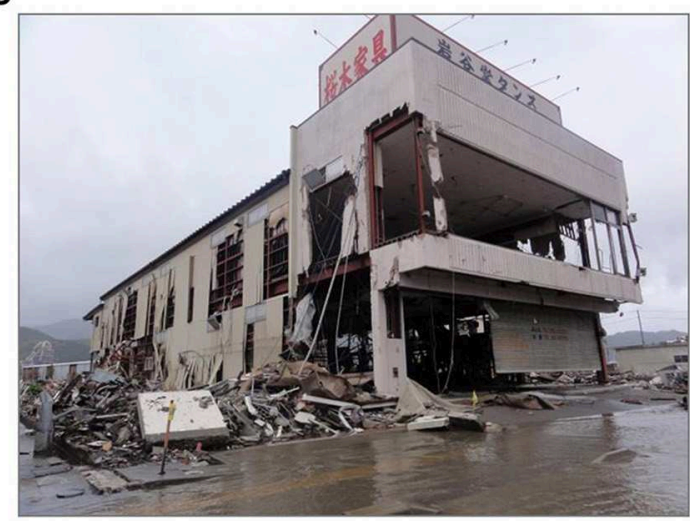

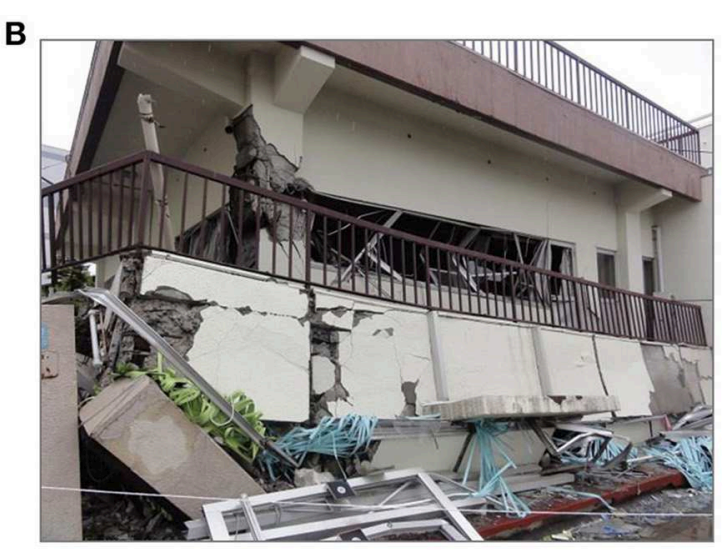

D

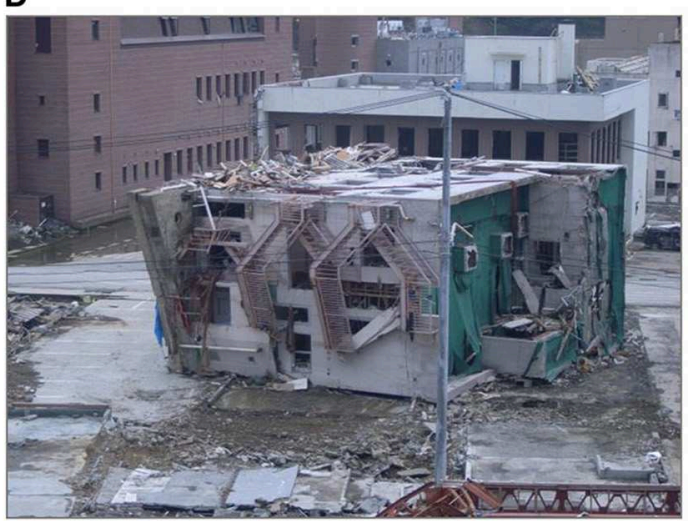

FIGURE 6 | Structural damage following the Tohoku earthquake. (A) Buckling at mild-span of column of Sukagawa city office building. (B) Soft story collapse of RC building at Sendai. (C) Damaged steel frame building at Ofunato. (D) Overturned RC building at Onagawa.

observed in several buildings (see Figure 7A). Column failure due to insufficient and poor shear design and detailing were also observed, some with poor lapping of link without $135^{\circ}$ bend (see Figures 7B-D). There were also occasions where concrete cover was insufficient or missing $(0-20 \mathrm{~mm})$, which led to corrosion to the steel.

Most seismic induced soft-story collapse failures occur particularly at the ground level where there exist columns with minimal infill walls or simply due to higher loadings transferred from upper stories. Such typical soft-story failures, alike to those observed at Padang and Tōhoku, were observed as shown in Figure 8A. However, in contrast, there were also observations of upper floor soft-story failures in a number of buildings following this Muisne earthquake. Change in stiffness of the story or plan was one of the key factors leading to such occurrence of upperstory collapses. Examples include the Magistrate building and a commercial building in Portoviejo and Manta, respectively, where discontinuity of stiffness was observed, as shown in Figures 8B,C. There were however occasions where upper softstory collapse occurred on buildings without obvious change in structural stiffness, plan or story height (e.g., Figure 8D). Further investigation appeared to confirm that such failure could be due to extension of the building long after the bottom floors were completed. Such practice appears to be rather prevalent in these towns (see Figure 9), although several other countries do have similar practices such as the Beşkats in Turkey and in Greece. The joints between new and old were typically poorly executed with insufficient lapping of the rebar, resulting in weak and brittle connection with local reduction in capacity, hence promoting failure in these areas. Such findings are alike to failures observed in post-earthquake reconnaissance to Turkey and Greece (Earthquake Engineering Field Investigation Team (EEFIT), 2003; Pomonis et al., 2011). In addition, the reinforcement bars often left out for many years can experience surface corrosion, which weaken their bond to the new concrete during casting. Such localized upper-story damage may also be attributed to all rebar being lapped at one height, resulting from the use of the same length bars in all columns. The increased axial loads would also cause more severe problems for the bottom floors.

Figure 10 compares the spectral accelerations recorded at stations in Pedernales, Manta, and Portoviejo, with the average damage grades of RC and timber/bamboo structures of different fundamental periods estimated based on their typology and height. It can be observed that higher grades of damage generally coincide with higher spectral acceleration of the shaking in 

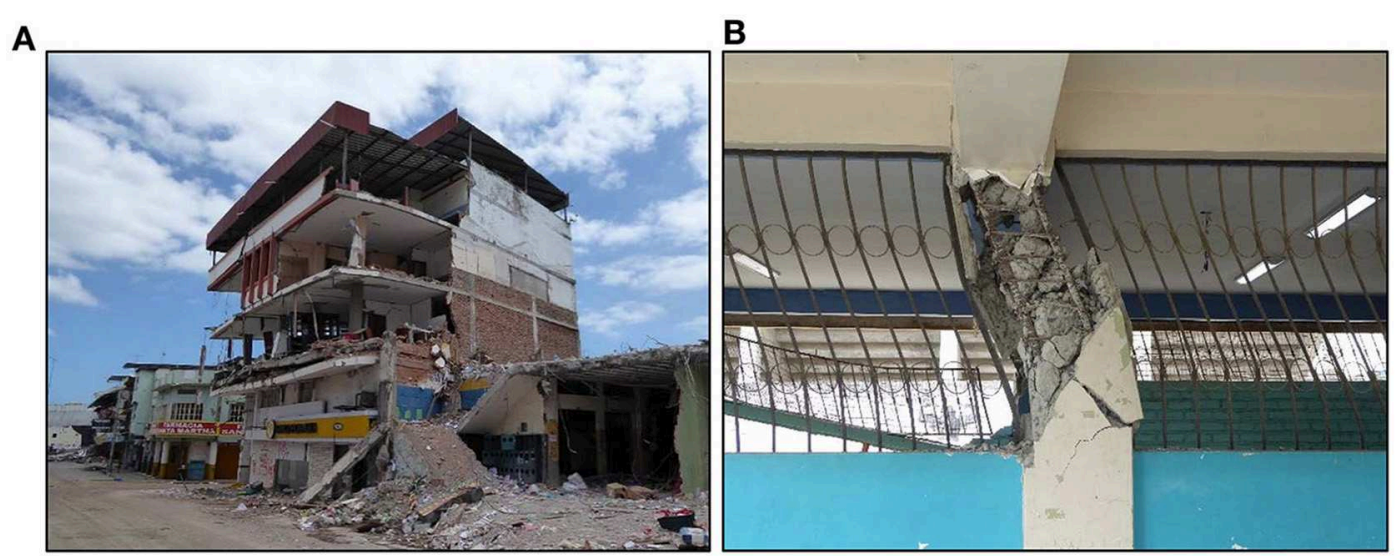

C

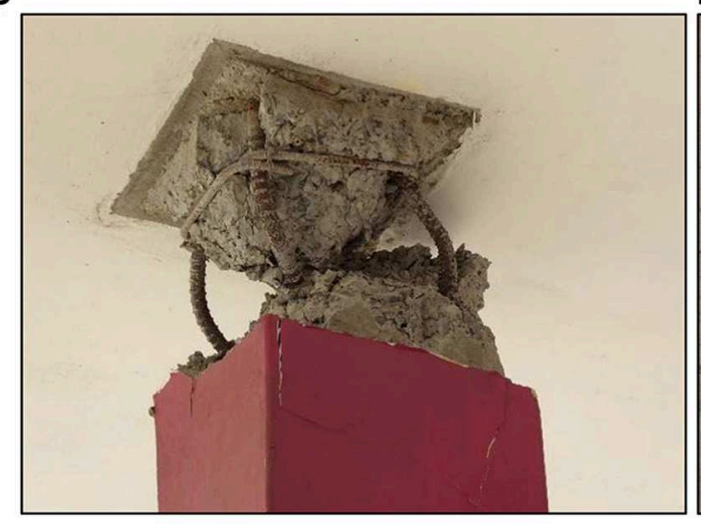

D

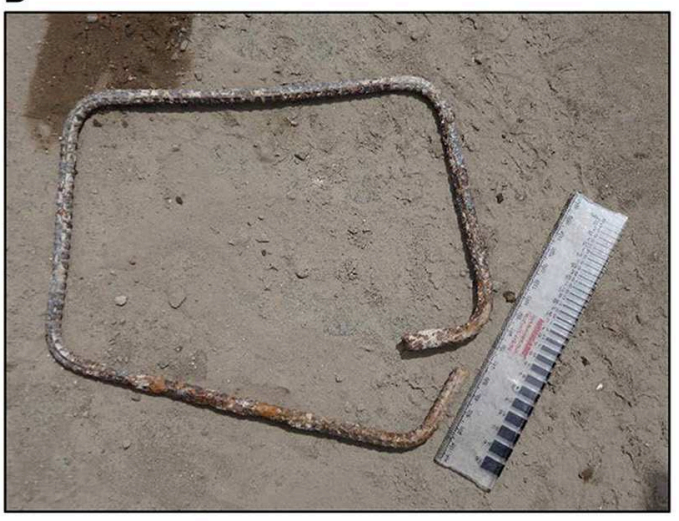

FIGURE 7 | Failures caused by inadequate design of infills and reinforcement detailing following the Muisne earthquake. (A) inadequate design/detailing of RC frame and infills at Portoviejo. (B) School building with short column failure at Pedernales. (C) Column head failure showing insufficient shear design at Portoviejo. (D) insufficient lapping of column link with no $135^{\circ}$-bend at Manta.

Pedernales, Manta and Portoviejo at similar periods. This confirms damage attributed to structural resonance which is in line with findings in Padang and Tōhoku earthquakes. Significant damage was observed for two- to five-story buildings at Pedernales which coincides with the dominant periods of 0.2 and $0.5 \mathrm{~s}$. Similarly, two- to four-stories buildings were observed to be most heavily damaged at Manta and Portoviejo, respectively which coincides with young Quaternary sediments according to the geological map in Figure 3B. In contrast, highrise buildings $>10$ stories were most affected at Chone where dominant shaking period was $1.3 \mathrm{~s}$. It is worth noting that earlier versions of the seismic code in Ecuador (e.g., Código de Práctica Ecuatoriano, 2001; CPE INEN 5:2001) were based on US seismic codes of the time (e.g., Uniform Building Code, 1997). The latest version has been updated in recent years (Norma Ecuatoriana de la Construcción, 2015), maintaining however the manner in which seismic actions are derived. Microtremor recording using a TROMINO Zero ${ }^{\circledR}$ instrument, non-invasive, passive geophysical method, was conducted at several locations in Manta, Portoviejo, Pedernales, and Bahia to ascertain the fundamental frequency and shear wave velocity profiles for each site for site response analysis. The method is based on measuring ambient seismic noise and translating it through time domain and spectral techniques (Nakamura, 1989). Measurements were taken close to the locations of strong ground recording stations installed by the Instituto Geofísico in Pedernales and Portoviejo. Figure 11 shows the comparison of the H/V ratio measurement and shear wave velocity profile at Manta, Portoviejo and Pedernales. Further details of the microtremor analysis can be found in the reconnaissance report [Earthquake Engineering Field Investigation Team (EEFIT), 2016].

In summary, structural resonance was observed to be one of the factors leading to heavy damage to buildings as evident in the Padang and Muisne earthquakes. The observation of few number of near-collapse buildings despite the strong shaking but non-coinciding ground shaking versus building frequencies at Sendai city near the epicenter of the Tōhoku earthquake is another evidence of importance of resonance effect to buildings. Insufficient and poor reinforcement detailing was observed in severely damaged buildings in all three earthquakes, most of which were designed based on older version of building codes. The minor or no damage to recently constructed buildings in these three countries also showed that modern building codes adopted are largely able to offer sufficient seismic resistance against severe damage if followed diligently. 
A

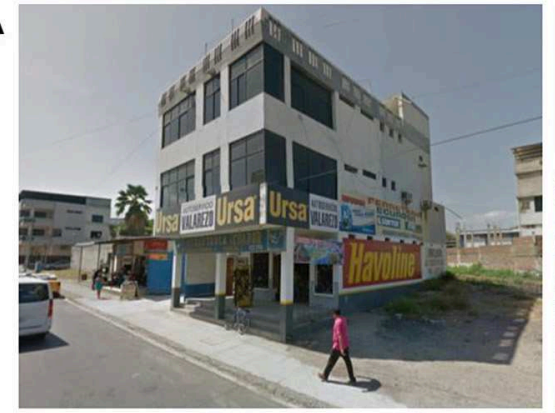

Before earthquake (Source: Google Maps)

B

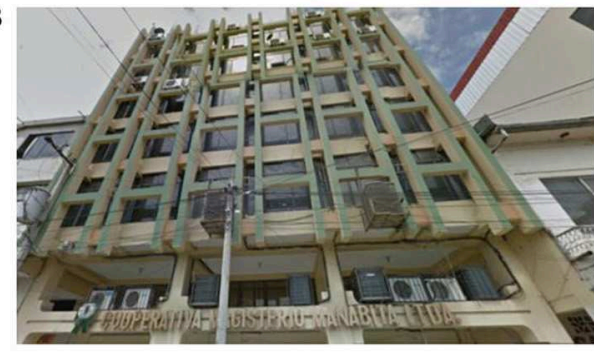

Before earthquake (Source: Google Maps)

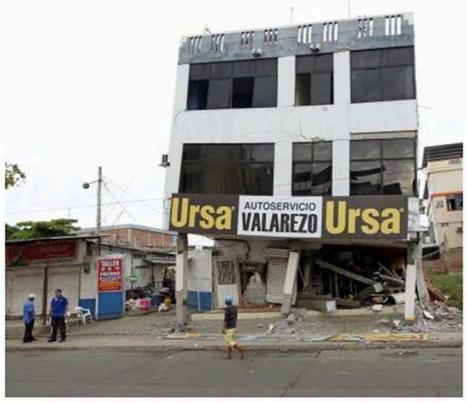

After earthquake

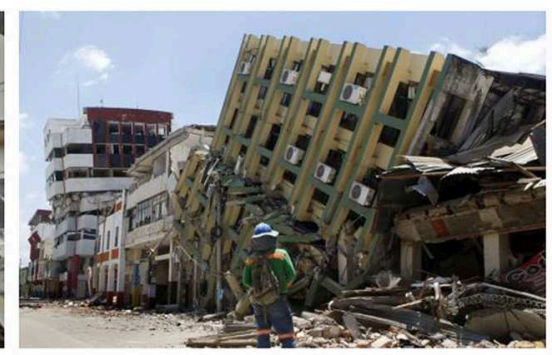

After earthquake

C
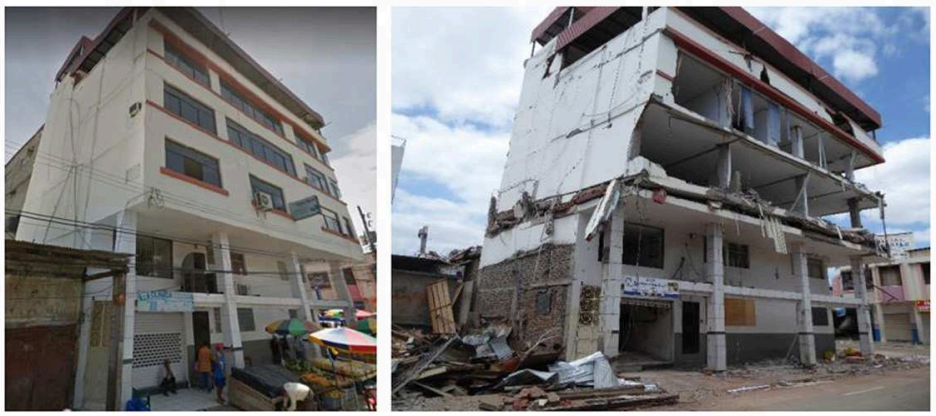

Before earthquake (Source: Google Maps)

After earthquake
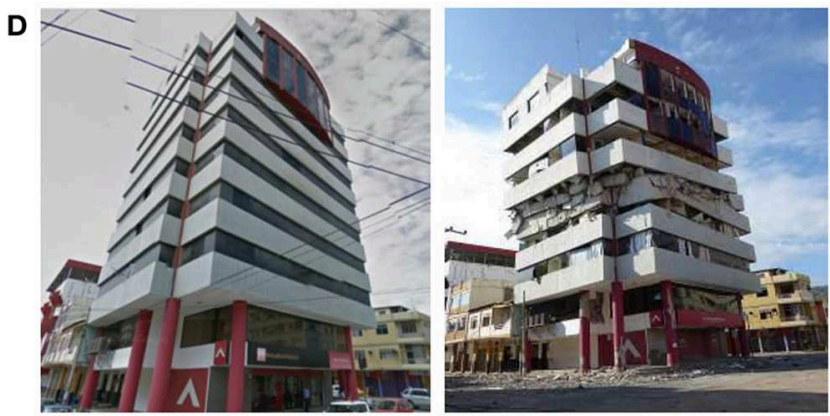

Before earthquake (Source: Google Maps)

After earthquake

FIGURE 8 | Soft story collapse following the Muisne earthquakes. (A) soft story collapse at groung level of car garage at Manta. (B) Upper story collapse at the Magistrate building at Potoviejo due to change in stiffness at 1st floor. (C) Upper story collapse at commercial building at Manta due to change in stiffness at 2nd floor. (D) Upper story collapse at Mutualista Pichincha building in Portoviejo. 

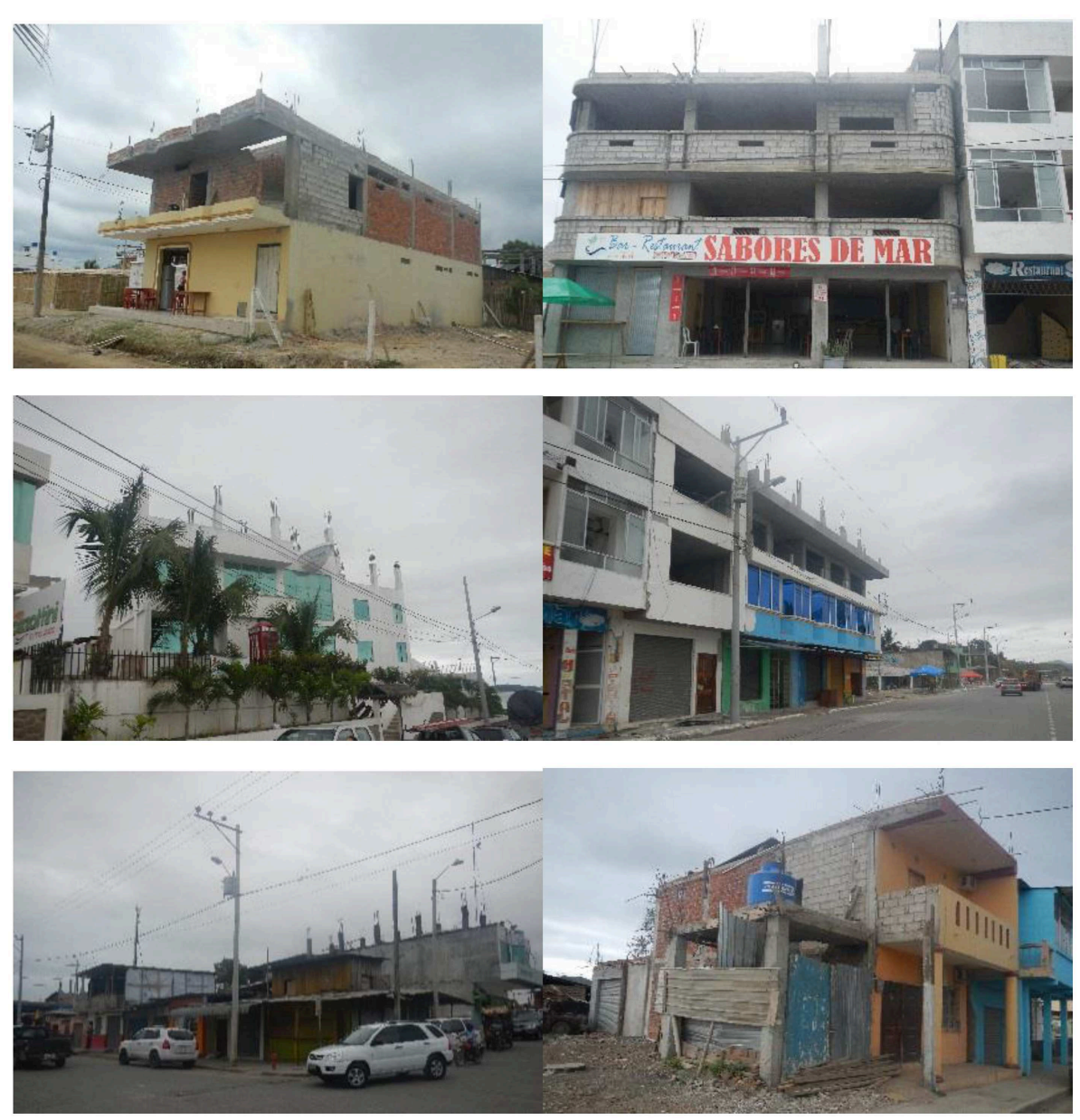

FIGURE 9 | Exposed reinforcement for future extension of building observed in various affected towns in Ecuador.

\section{DAMAGE TO FOUNDATIONS}

\section{The 2009 Padang Earthquake}

Following the 2009 Padang earthquake, observations of foundation failures were minimal with foundations of buildings mostly intact with some minor settlement in the region. One of the university buildings in Universitas Negeri Padang with pile foundation had suffered slight differential settlements. This led to cracks and settlements of non-suspended slabs in one of the adjoining classrooms. The pile foundations were found on deep stiffer soil, which did not settle as excessively as the surrounding ground. Therefore support to key structural members such as columns and beams performed well with minimal structural damage. Figure 12A illustrates the settlement of the surrounding soil of about $100 \mathrm{~mm}$ relative to the pile foundation. Coarse sand deposits were found in this area.

\section{The 2011 Tōhoku Earthquake}

Similar observations were made in the Tōhoku earthquake, particularly in Sendai city where it is closest to the Mw9.0 epicenter. RC buildings found on deep pile foundation suffered lower settlement relative to the surrounding ground
(Figure 12B). Foundations of a handful of lower rise buildings of expectedly shallower foundation penetration depth sank relative to the surrounding ground level (Figure 12C). Other attributing factors could be due to soil liquefaction as evident with occurrence of sand boils and ground settlement measuring as much as $70 \mathrm{~mm}$ nearby. In the affected areas, ground settlement caused tilting of high rise buildings (Figure 12D) and affected the use of external staircases and roadways leading to carparks. In some cases, differential settlement rendered apartment buildings unsuitable for occupancy and had to be demolished. Overturning of buildings due to impact of the tsunami mainly occurred to buildings with shallow foundation or slender piles. Soil liquefaction can allow piles to be pulled out of the soil more easily. Scouring due to fast-flowing tsunami waves around buildings also reduces ground bearing support which led to tilting of buildings as shown in Figure 12E. Coastal subsidence of more than $0.5 \mathrm{~m}$ in numerous coastal towns and cities also caused these shorelines to suffer frequent tidal flooding.

\section{The 2016 Muisne Earthquake}

At Ecuador, the reconnaissance also covered the Mejia Bridge on the 39A between Rocafuerte and Portoviejo where the bridge 


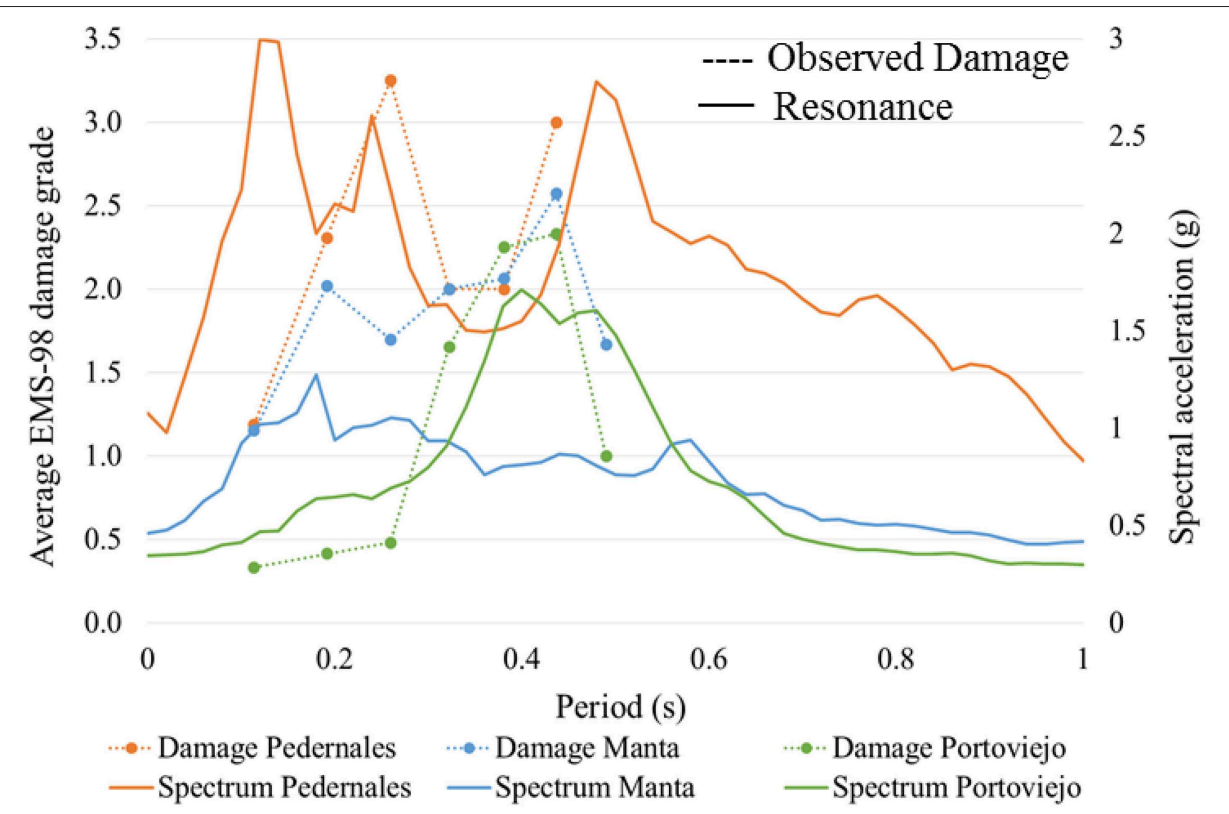

FIGURE 10 | Relationship between response spectra from recorded ground motions and surveyed building damaged (Franco et al., 2017).

foundation suffered excessive settlement and lateral spreading at the southern road entrance of the bridge. The location of bridge was along the narrow channel of young sediment deposit extending northwest to Crucita based on the geological map. Ground settlements of up to $1.1 \mathrm{~m}$ and lateral spreading as much as $3 \mathrm{~m}$ of the road embankment were observed. At the time of the survey, the surface of the approaches had been repaired, although sizeable settlement and rotation of the gabions on the river bank on the south west side of the bridge were observed (see Figure 12F). Heavy rain and flooding in the region during the days leading up to the earthquake could have raised the ground water table level, making ground more susceptible to liquefaction.

Based on the above observations in these three earthquakes, deep foundations performed well due to their founding on deep stiff stratum. Exceptions were caused by soil liquefaction which could have reduced the end bearing and skin friction at the interface of the pile and soil, thereby leading to more significant settlement. Foundations sited on slopes may suffer from lateral spreading as observed at Mejia Bridge following the Muisne earthquake. In the case of tsunami, building foundations were either sheared or pulled off under the horizontal force of the oncoming water exerted onto the building walls if water was not permitted to pass through the interior of the buildings.

\section{SOIL LIQUEFACTION}

Despite soil liquefaction being commonly observed in the three earthquake events, the direct consequence was not severe.

\section{The 2009 Padang Earthquake}

In some areas of Padang, liquefaction occurred largely attributed to the high sand content and water table present along its low coastal strip plain. The tension cracks on the road and near the beach were the consequence of lateral spreading as portrayed in Figure 13A. Landwards into the Padang city center, the Mere Amelie Church suffered effects of liquefaction as well. Sand boils were observed in the school beside the church (Yayasan Prayoga SD Agnes). These sand boils were predominantly silty sand which came from the soil deep beneath the topsoil. In lowlying land regions, clear signs of liquefaction were also sighted as evident from a well in Siteba Village which had been choked by the rising sand due to the build-up of pore water pressure during the earthquake. The excavated soil was investigated and found to be uniformly graded fine sand, confirming liquefaction susceptibility. In nearby Perumdam Village, two adjacent singlestory houses near the river had suffered from the effects of liquefaction. Excess pore water pressure had built up below suspended floor slabs, leading to the upheaval of the slabs as shown in Figure 13B. Once the cracks in the floor slabs had opened, the water could flow out, thus relieving the excess pore pressure and allowing the floor slabs to settle back.

\section{The 2011 Tōhoku and 2016 Muisne Earthquakes}

In Japan following the Tohoku earthquake, liquefaction induced uplift of manholes and lateral spreading were also observed in Shirakawa and Sendai (Figure 13C). In Ecuador, evidence of earthquake-induced soil liquefaction, such as ground settlement and uplift of underground pipes and manholes, was observed at several locations visited in the Manabí province. Along the seafront in Pedernales, settlements of $100 \mathrm{~mm}$ were observed on interlocking block pavements (Figure 13D) with manholes protruding by some $30 \mathrm{~mm}$ (Figure 13E). The former was attributed to the compaction of loose soil deposits under strong 

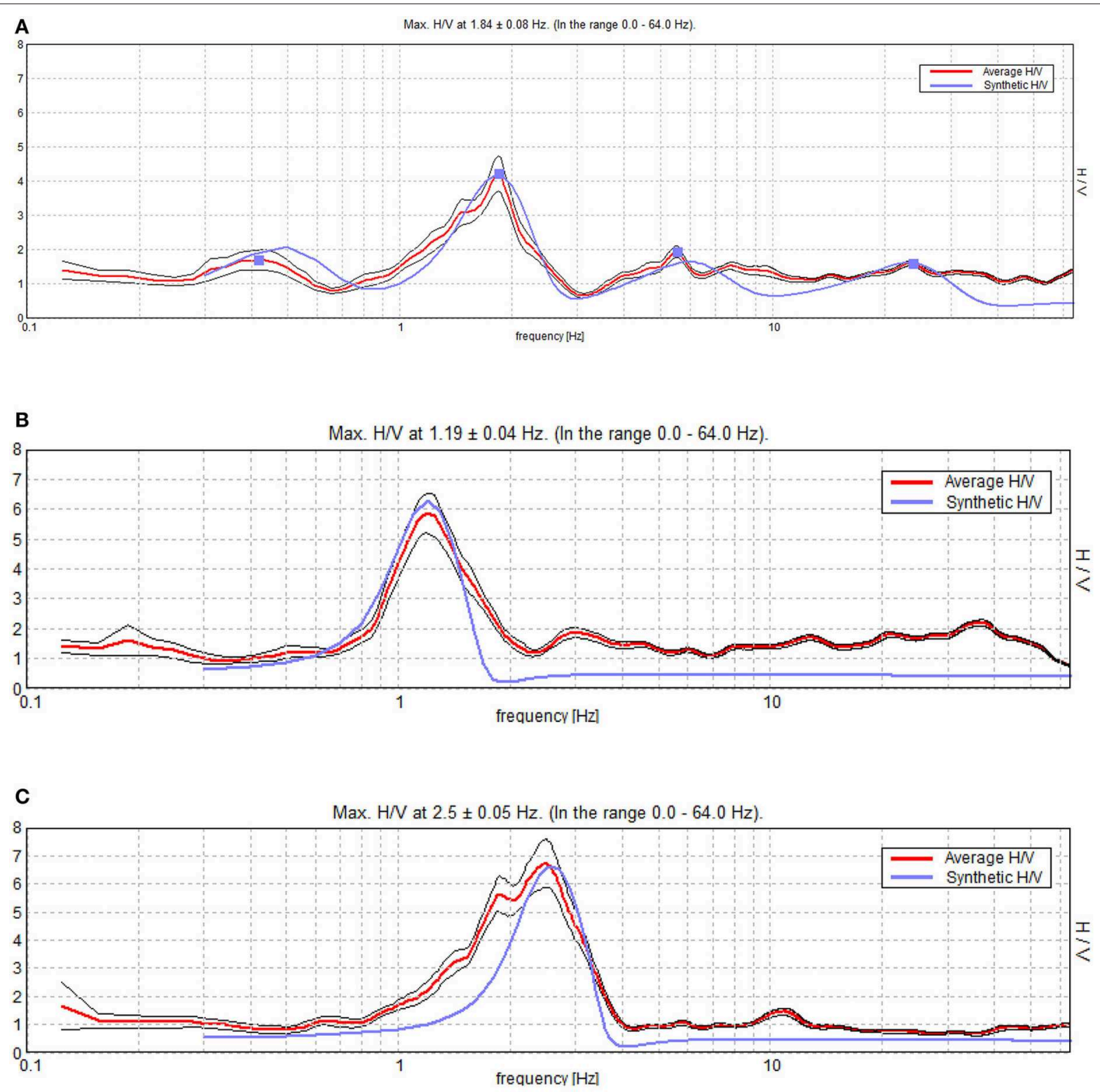

FIGURE 11 | H/N ratio measurements and derived spectrum from in situ shear wave velocity at various sites in Ecador. (A) Tarqui, Manta. (B) River Bank, Portoviejo. (C) Seismic measuring station APED, Pedernales.

shaking, while the latter caused by buoyancy of the underground utilities due to lower unit weight as compared to the surrounding liquefied soil.

\section{FAILURE OF SLOPES AND RETAINING STRUCTURES}

\section{The 2009 Padang Earthquake}

Landslides at Padang were widespread in the mountainous topography landwards of Pariaman. Figures 14A,B show two of the several landslide sites visited in the worst-affected district of Nagari Tandikek in Pariaman. Two villages, Pulau
Air and Cumanak, were severely affected by these landslides. Roads perpendicular to the landslide runoff were buried which disrupted rescue operations. The landslide site at Kapalo Koto, a part of the Pulau Air Village, was buried by the landslide. The concrete slab foundation and brick and timber debris of the destroyed Kapalo Koto elementary school were the only remains in the site. Located near Mount Tandikek, a dormant volcano, the agriculturally-intensive Cumanak Village experienced the largest landslide with the highest number of causalities. A contributing factor to the large landslides was the heavy rainfall on the morning of the landslide. The infiltrated rainfall led to slope instability due to the reduced effective shear strength of the 


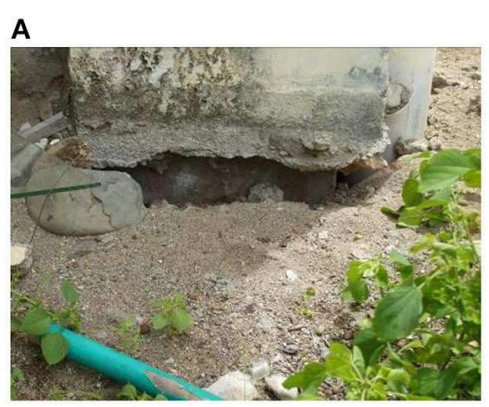

B

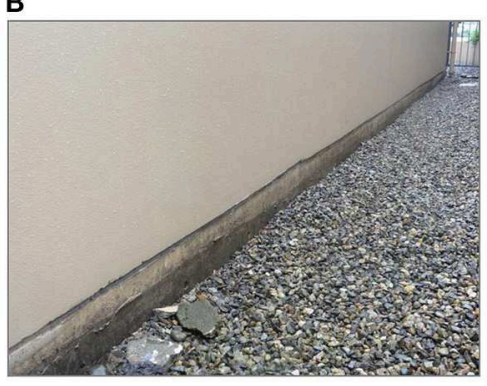

D

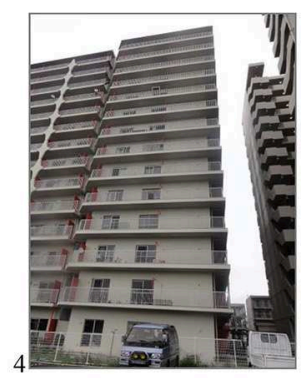

F

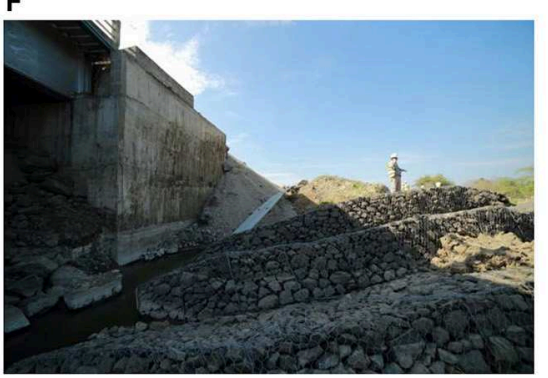

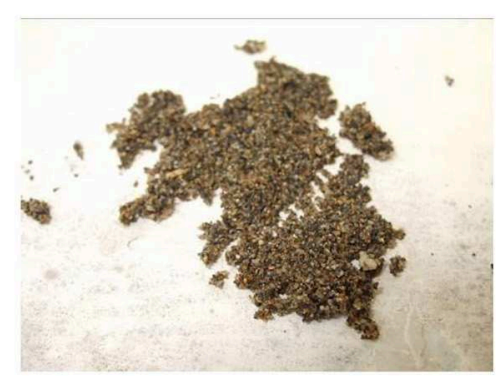

\section{C}

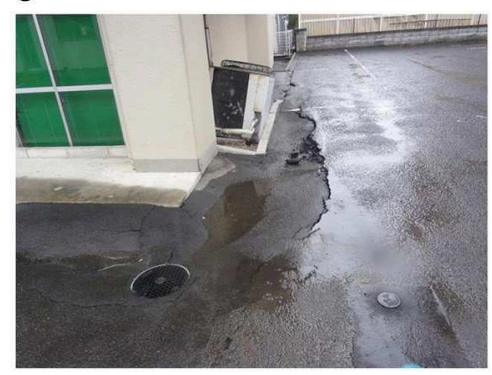

E

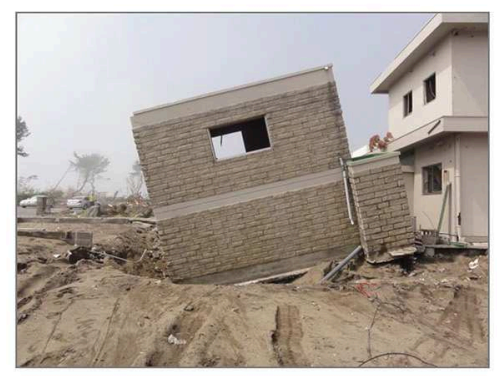

FIGURE 12 | Foundation and ground failures following Padang, Tohoku and Muisne earthquakes. (A) Settlement of ground around column where sand was found in the proximity. (B) Ground settlement around building at Sendai. (C) Sinking of building relative to surrounding at Sendai. (D) building tilt due to differential settlement at Sendai. (E) loss of soil bearing due to scour at sendai. (F) settlement and rotation of gabions on the river bank Mejia bridge.

soil during the earthquake. Some of the soil collected from the surface of the landslide debris was weathered pumice, ranging in size from sand to fist-size rock, with the majority having grain sizes $<10 \mathrm{~mm}$. Such lightweight and porous material typically originate from volcanic rocks which underwent rapid cooling and depressurisation when they were violently ejected from a volcano. The high number of casualties at these landslide sites was also attributed to the coincidence of a large village wedding ceremony taking place when the earthquake struck. Numerous timber houses were swept away by the landslide. Due to the hilly and forested terrain accompanied with roads being buried by the landslide, the site was difficult to access, delaying search and rescue efforts after the earthquake for approximately 4 days. The situations were made worse by a damaged pedestrian bridge which was the sole passage leading to the site. 
A

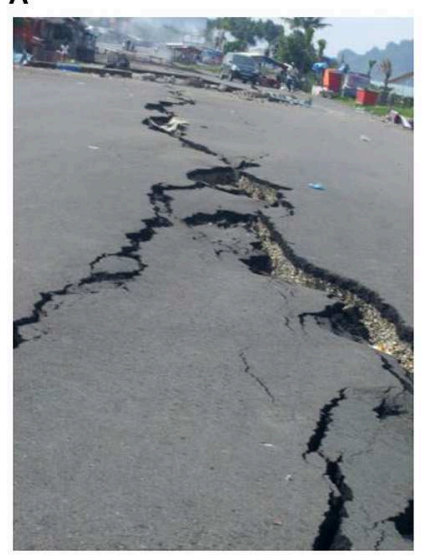

C

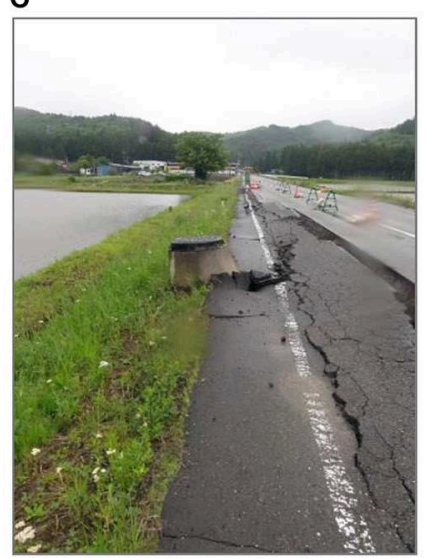

D

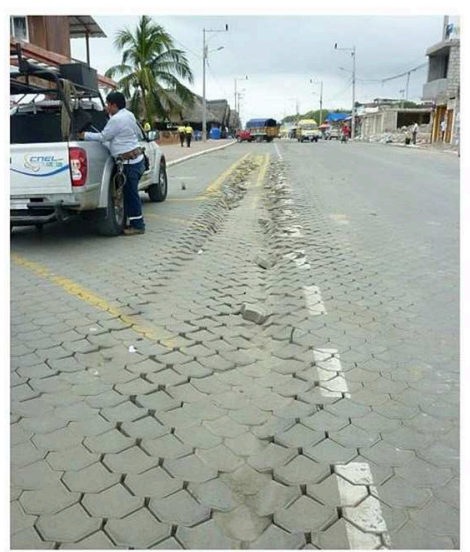

B

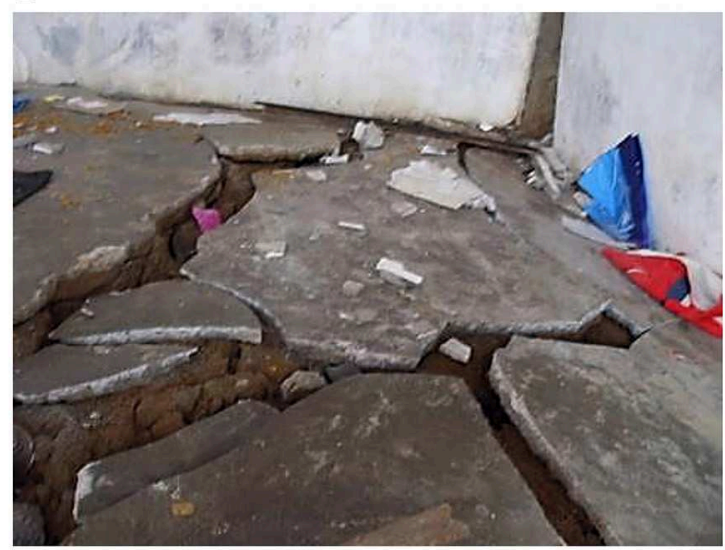

E

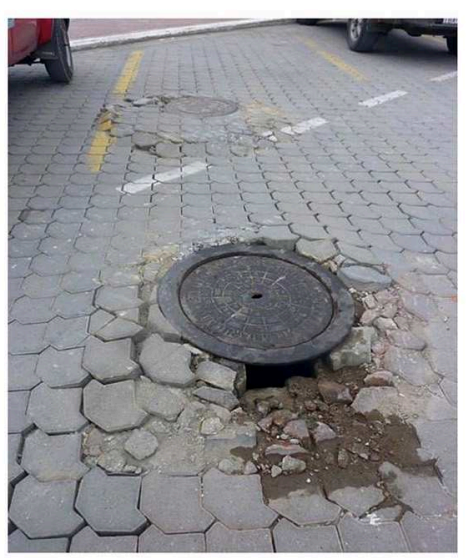

FIGURE 13 | Consequence of soil liquefaction following the Padang, Tohoku, and Muisne earthquakes. (A) Tension cracks arising from lateral spreading at Padang city. (B) upheaval of floor slabs of village house due to liquefaction at Perumdam Village, Padang. (C) Uplift of manhole and lateral spreading at Shirakawa. (D) ground settlement on pavement at Pedernales. (E) uplift of manhole close to the observe ground settlement at Pedemales.

The 2011 Tōhoku and Muisne Earthquakes

In Japan, earthquake-induced slope failures resulted in damage to low-rise residential wooden houses in Oritate, Sendai. The strong shaking also led to the failure of the gravity stone retaining walls at Komine Castle in Shirakawa due to insufficient horizontal ties within the cobble rocks. Large-scale landslides buried roads 


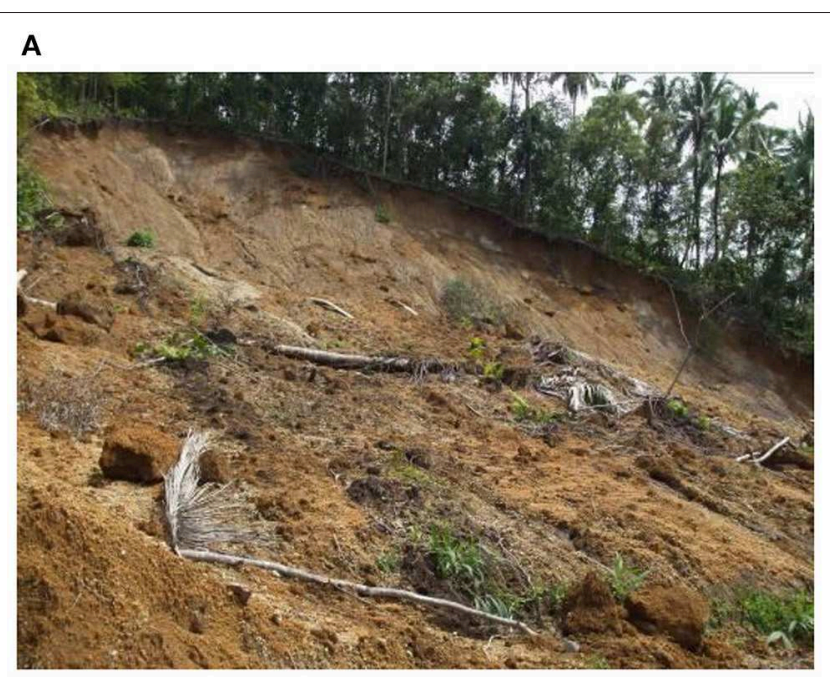

B

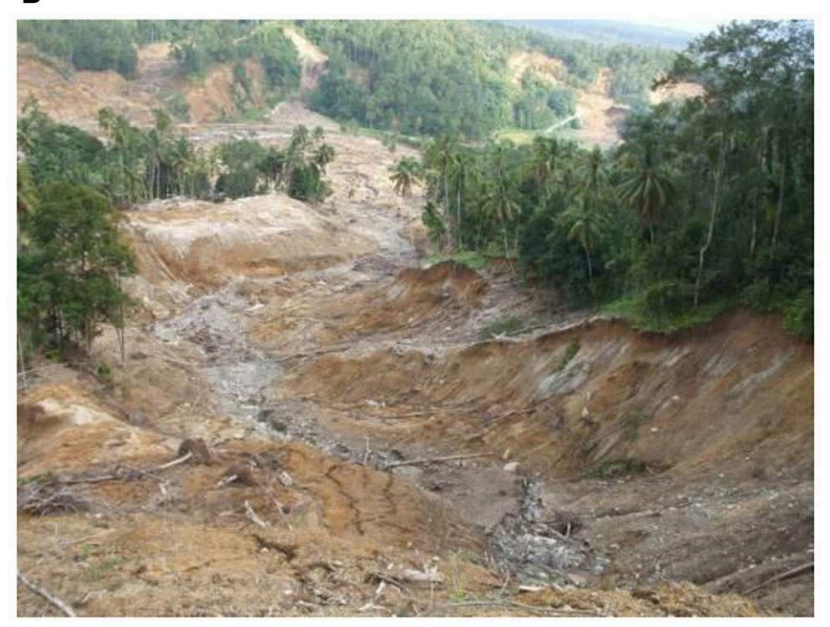

c

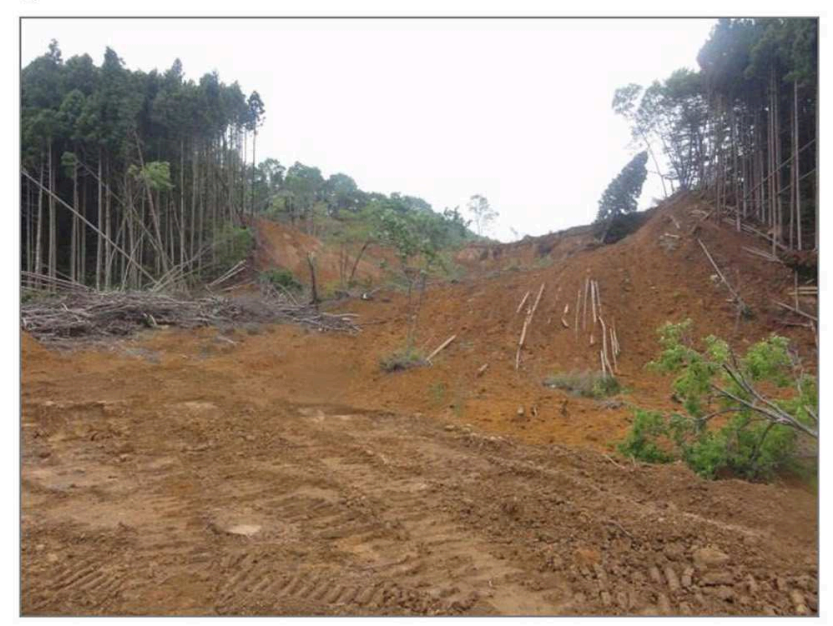

FIGURE 14 | Landslide following the Padang and Tohoku earthquakes. (A) A slip-circle landslide failure at Pulau air village, Pariaman. (B) An infinite-slip slope landslide at Cumanak village, Pariaman. (C) Earthquake-induced landslide at Shirakawa. and houses at the foot of slopes, resulting in traffic disruption, property losses and 13 casualties in Shirakawa as shown in Figure 14C. In Ecuador, numerous landslides were observed along the coast between San Vincente and Canoa, where the Northern Bahia Fault is mapped. These slope instabilities, also present along the southern coastal cliffs close to Bahia and in many places in the estuary, were attributed to excavation of steep slopes for road construction. The San Isidro section of the Canaveral Fault may also have aggravated the damage in the region following the earthquake. Other contributing factors leading to greater severity of slope instability include: (1) greater saturation of water in soil due to heavy rainfalls leading up to the time of earthquake, (2) lateral spreading from liquefaction of soft alluvial soil layers causing slippage at weak interfaces near the surface of slope, (3) lack of stabilization at man-made cut slopes, (4) river bank management leading to increased stream velocities which loosen or erode earth embankments, and (5) flood plains next to vulnerable man-made slopes (e.g., Portoviejo).

Following lesson learnt from these events, the effects of landslides could be alleviated by: (1) mapping landslide risk in the region for planning of urgent slope stabilization works, (2) installing drainage systems to avoid high pore water pressure build-up, (3) implementing stabilization techniques with vegetation, shotcrete or anchors, and (4) active monitoring of unstable slopes particularly after rainy seasons so as to provide timely mitigation measures. Subsequent section of this paper would discuss further with an example on the use of geospatial tools for mapping landslide risks.

\section{USE OF GEOSPATIAL TOOLS}

In recent years, advances in geospatial tools have encouraged EEFIT to adopt their use in field missions. The events described exemplify the use of such tools to better analyse damage due to landslides in relation to spatial and ground conditions.

\section{The 2009 Padang Earthquake}

In view of the large extent of landslide occurrences in Padang, the team was particularly interested in investigating the capability of using remote sensing technologies to characterize earthquakeinduced landslides. Four sources of data were applied to identify the boundaries of two landslides to determine the consistency between these data sources: Global Positioning System (GPS) survey readings collected on-site, a three-dimensional Digital Elevation Model (DEM) from the Advanced Spaceborne Thermal Emission and Reflection Radiometer (ASTER), two-dimensional post-disaster satellite imagery from Satellite Pour L'Observation de la Terre (SPOT) acquired by CRISP NUS, and the Google ${ }^{\text {TM }}$ Earth base. The on-site GPS survey readings were collected via a TOPCON GPS hand-held receiver electronically based on the average coordinates from three strong signal-emitting satellites within the vicinity. The ASTER DEM has a spatial resolution of approximately $30 \mathrm{~m}$. The SPOT-5 satellite imagery has a spatial resolution of $10 \mathrm{~m}$. The Google ${ }^{\mathrm{TM}}$ Earth base is constructed with Landsat satellite images of $15 \mathrm{~m}$ and SRTM DEM of assumed 


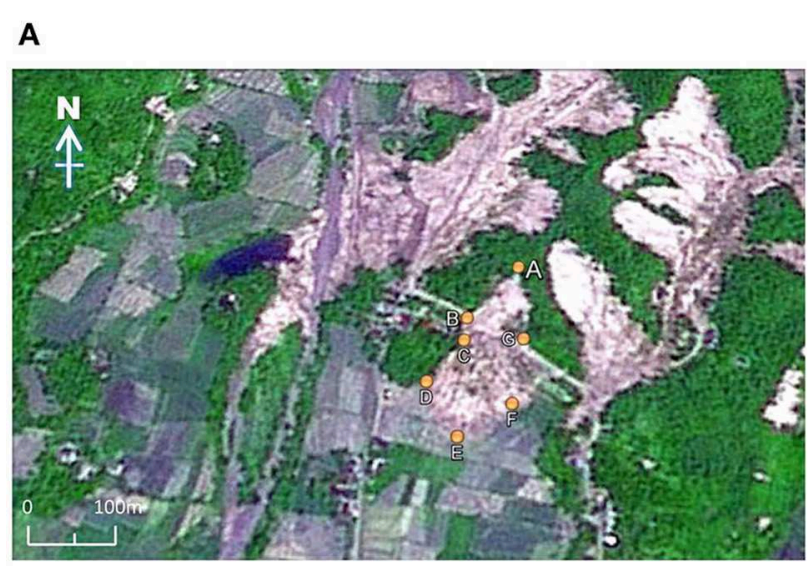

B

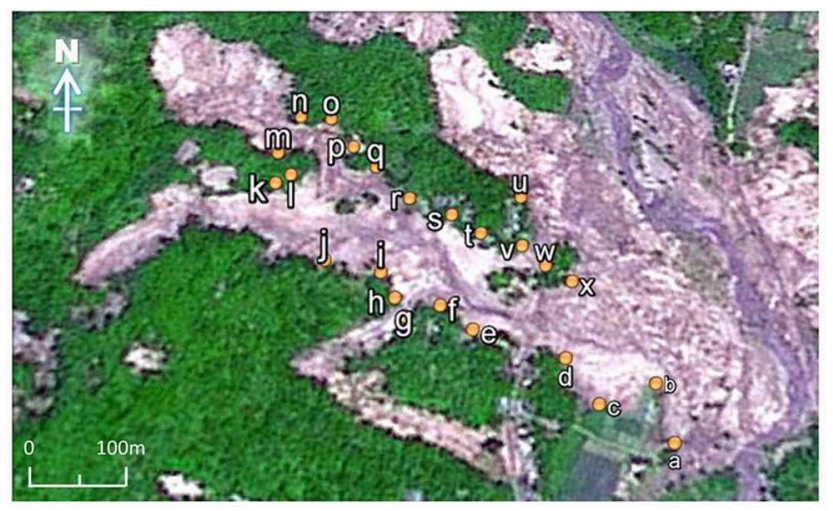

C

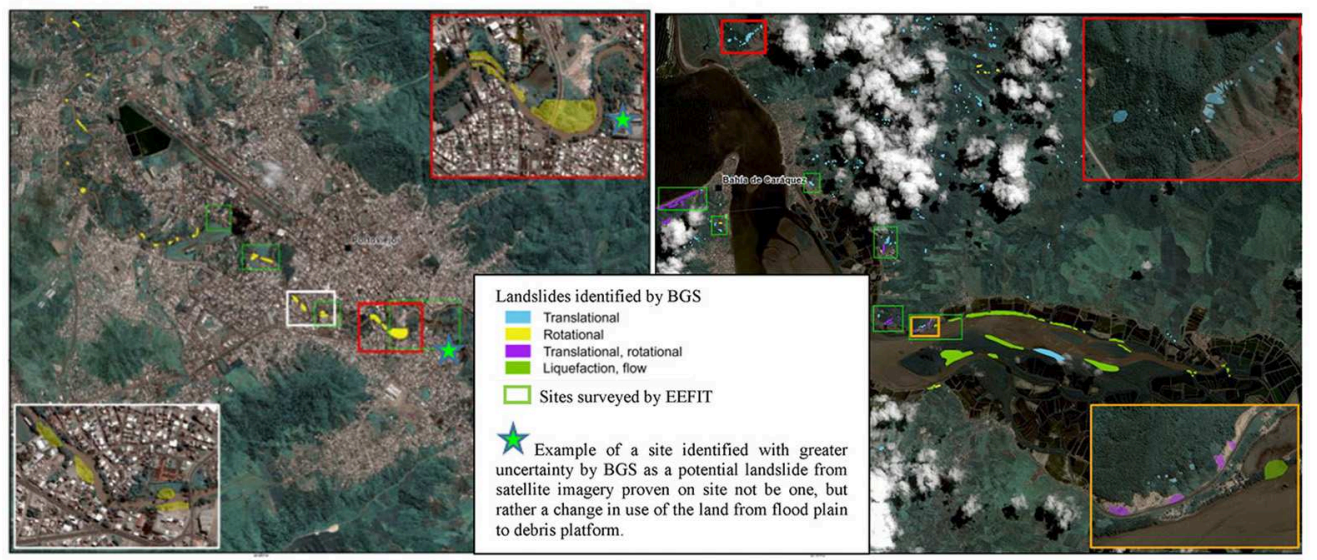

FIGURE 15 | Landslides in Sumatra and Ecuador identified from satellite imagery. (A) Locations of Landslide I boundary points at Pariaman, superimposed on SPOT-5 satellite image, acquired by Center for Remote Imaging, Sensing and Processing, National University of Singapore. (B) Locations of Landslide II boundary points at Pariaman, superimposed on SPOT-5 satellite image, acquired by Center for Remote Imaging, Sensing and Processing, National University of Singapore. (C) Landslide in Ecuador identified from satellite imagery, left: Portoviejo; right: Bahia de Caraquez (British Geological Survey, 2016a,b).

$90 \mathrm{~m}$ in spatial resolution. Landslide $I$ (a small landslide at Pulau Air Village, Figure 15A) and Landslide II (a large scale landslide at Cumanak Village, Figure 15B) were selected to: (1) assess repeatability between different data sources, (2) ascertain any influence the size of landslide may have on the deviation in coordinates between data sources, and (3) determine the range of difficulties likely to be encountered when collecting such field data. A number of points along the boundaries of the two landslides were selected for the comparison of aerial coordinates and elevation between the different data sources. 
Detailed analysis was presented in Chian and Wilkinson (2015). In summary, results indicate that all sources which demonstrate an acceptable and consistent level of accuracy for landslide hazard assessments within the region, and across landslides of differing scale. There were consistent horizontal coordinates for the edge of the landslide [maximum root mean square (RMS) difference in coordinates between all data was 0.37 arc seconds or $11.4 \mathrm{~m}$ ] The maximum RMS difference in elevation between GPS survey, Google ${ }^{\mathrm{TM}}$ Earth and the ASTER DEM displayed reasonable difference of between 0.5 and $19.2 \mathrm{~m}$. This range is in the same order as the height of the vegetation within the survey region (the tree height was estimated to be between 5 and $15 \mathrm{~m}$ ). These results are in agreement with validation reports of the STRM-based Google ${ }^{\mathrm{TM}}$ Earth and ASTER DEMs (Smith and Sandwell, 2003; Tachikawa et al., 2011). Despite the larger extent of Landslide $I I$ in comparison to Landslide $I$, the maximum RMS difference in longitude and latitude of Landslide II (approximately 0.24 arc s or $7.3 \mathrm{~m}$ ) is similar to Landslide $I$.

\section{The 2016 Muisne Earthquake}

Initiated by a request from the UK Department for International Development (DfID), a collaboration with the British Geological Survey (BGS) was made to ascertain the feasibility of using satellite imagery for rapid preliminary landslide assessment to enhance response operations, road clearing, and emergency route identification. The satellite imagery was provided by UNITARUNOSAT (2016) to BGS. Guided by the satellite images offered by BGS, field validation of these identified landslides was carried out as part of the ground-truthing exercise (see Figure 15C). A total of 13 and 17 sites were surveyed and validated in Portoviejo and in the vicinity of Bahía de Caráquez, respectively. Coseismic landslide field surveys also permit better understanding of the residual vulnerabilities of slopes after an earthquake which may develop into more severe consequences in future heavy rainfalls or seismic events. Out of 30 landslide locations investigated, about $80-90 \%$ of suspected landslides in satellite imagery were correctly identified, providing validation for the satellite-imagery interpretation, with occasional non-detection of small-scale landslides and false identification of landslide occurrence [Earthquake Engineering Field Investigation Team (EEFIT), 2016]. Validation of this method of satellite-based landslide identification gives confidence in using this method to identify and remotely analyse landslides which would otherwise have been difficult to access due to dense vegetation and unstable ground conditions, such as the liquefaction induced failure along the Chone Estuary, close to Bahía de Caráquez.

\section{CONCLUSIONS}

Following the analysis of the field missions to the $\mathrm{M}_{\mathrm{w}} 7.6$ 2009 Padang earthquake in Indonesia, $\mathrm{M}_{\mathrm{w}} 9.02011$ Tōhoku earthquake in Japan and $M_{\mathrm{w}} 7.82016$ Muisne earthquake in Ecuador, the following are the lessons learnt from these events:

1. Soft-story collapse was by far the major structural failure mode observed in engineered buildings in the three earthquake events. More often, they occurred on older age buildings. The insufficient and poor reinforcement detailing such as use of smooth bars for links and main reinforcement, large spacing between confining links, and insufficient hook length and angles further exacerbate the susceptibility to severe damage of these buildings following older version of building codes. It is therefore recommended that buildings constructed prior to year 2002 in Sumatra Indonesia, year 2000 in Japan, and year 2001 in Ecuador be reviewed for their vulnerability to modern threats of major earthquakes under the latest building codes. While general failure mechanisms can be broadly similar (e.g., soft-story), particular aspects of structural failure could be investigated further to determine the cause of subtle differences in future post-earthquake missions. In addition, seismic prone countries may like to assess if the extent of damage and casualties in recent earthquakes calls for a strong argument for more stringent building codes to be implemented.

2. Foundations generally performed relatively well in the three earthquake events, with the exception of cases where soil liquefaction occurred which led to severe ground settlement and loss of bearing support. It is therefore recommended that soil liquefaction susceptibility be assessed for critical infrastructures and buildings supported on shallow foundations. If deemed high risk, ground improvement such as dynamic compaction, grout permeation or installation of vertical drains may be adopted. Future missions may investigate further on the spatial distribution of liquefiable and soft ground conditions with geophysical testing methods along with existing borehole information. The effectiveness of liquefaction mitigation techniques should also be evaluated when ample time and opportunity arise.

3. Widespread landslides occurred in all three earthquake events with severe consequences. Heavy rainfall leading to the occurrence of earthquake, coincidence of flood plains next to man-made slopes, poor river bank management and drainage and highly liquefiable soil near the surface can lead to greater severity of slope stability. In view of these concerns, development of reliable landslide hazard maps, active monitoring of potentially unstable slopes and implementation of slope stabilization techniques should be considered. Following the use of geospatial tools involving GIS based landslide hazard mapping analysis and landslide satellite identification in Sumatra and Ecuador respectively, results have demonstrated their effectiveness in hazard identification prior and after a major earthquake. Adoption of similar methodologies should be encouraged so as to anticipate likelihood of landslide occurrence and respond more swiftly in search and rescue operations so as to reduce casualties and property losses in future major earthquakes to come.

This paper is one of the few publications involving the reporting of multiple earthquake events. In view of the variety of impacts observed in different events, more EEFIT reports would be compared and contrasted with the growing catalog of information so as to identify more startle patterns of damage and vulnerability in modern seismic design. 
This paper is dedicated to the victims of the 2009 Padang, 2011 Tōhoku and 2016 Muisne earthquakes, and seeks to motivate practicing and research communities toward reduction of loss of lives in such tragic events in the future.

\section{AUTHOR CONTRIBUTIONS}

All authors listed have made a substantial, direct and intellectual contribution to the work, and approved it for publication.

\section{ACKNOWLEDGMENTS}

The authors would like to express their thanks to the Engineering and Physical Sciences Research Council (EPSRC)

\section{REFERENCES}

Ammon, C. J., Lay, T., Kanaore, H., and Cleveland, M. (2011). A rupture model of the great 2011 Tohoku earthquake. Earth Planets Space 63, 693-696. doi: $10.5047 /$ eps.2011.05.015

Badan Nasional Penanggulangan Bencana (BNPB) (2009). Laporan Harian Pusdalops BNPB Minggu. Jakarta: Badan Nasional Penanggulangan Bencana.

British Geological Survey (2016a). Preliminary Co-seismic Landslide Inventory Map for Portoviejo. Keyworth: British Geological Survey.

British Geological Survey (2016b). Preliminary Co-seismic Landslide Inventory Map for Bahía de Caráquez. Keyworth: British Geological Survey.

Chian, S. C., Whittle, J., Mulyani, R., Alarcon, J. E., and Wilkinson, S. M. (2010). "Post earthquake field investigation of the Mw 7.6 Padang earthquake of 30 September 2009," in 14th European Conference on Earthquake Engineering (Ohrid) Paper ID 1372.

Chian, S. C., and Wilkinson, S. M. (2015). Feasibility of remote sensing for multihazard analysis of landslides in Padang Pariaman during the 2009 Padang earthquake. Nat. Hazards Rev. 16:05014004. doi: 10.1061/(ASCE)NH. 1527-6996.0000143

Código de Práctica Ecuatoriano (2001). Ecuadorian Building Code, General Design Specifications. Quito: Ecuadorian Standardization Institute.

Dirección de Geologiİ a y Minas (DGGM) (1982). Mapa Geológico Actualizado del Ecuador, escala 1:1'000.000. Quito: Instituto Ecuatoriano de Mineria.

Direktorat Penyelidikan Masalah Bangunan (1983). Peraturan Pembebanan Indonesia Untuk Gedung. Bandung: PPIUG.

Earthquake Engineering Field Investigation Team (EEFIT) (2003). The Kocaeli, Turkey Earthquake of 17 August 1999: Field Report, The Institution of Structural Engineers. Available online at: http://www. istructe.org/resources-centre/technical-topic-areas/eefit/eefit-reports (accessed January 15, 2019).

Earthquake Engineering Field Investigation Team (EEFIT) (2009). The Padang, Sumatra - Indonesia Earthquake of 30 September 2009: Field Report, The Institution of Structural Engineers. Available online at: http://www.istructe.org/ resources-centre/technical-topic-areas/eefit/eefit-reports (accessed January 15, 2019).

Earthquake Engineering Field Investigation Team (EEFIT) (2013). Recovery two years after the 2011 Tohoku Earthquake and Tsunami: A Return Mission Report, The Institution of Structural Engineers. Available online at: http://www.istructe.org/resources-centre/technical-topic-areas/eefit/eefitreports (accessed January 15, 2019).

Earthquake Engineering Field Investigation Team (EEFIT) (2016). The Muisne, Ecuador Earthquake of 16 April 2016: Field Report, The Institution of Structural Engineers. Available online at: http://www.istructe.org/resourcescentre/technical-topic-areas/eefit/eefit-reports (accessed January 15, 2019).

Earthquake Engineering Field Investigation Team (EEFIT) (2011). The Tohoku Earthquake and Tsunami of 11 March 2011: Field Report, The Institution of Structural Engineers. Available online at: http://www.istructe.org/resourcescentre/technical-topic-areas/eefit/eefit-reports (accessed January 15, 2019).
[Grant No.: EP/H043616/1, EP/I01778X/1, and EP/P025951/1], AIR Worldwide, Cambridge Architectural Research Ltd, Global Earthquake Model, Institution of Civil Engineers (QUEST Travel Award), Sasakawa Foundation, Sellafield Ltd., Willis Research Network, Guy Carpenter, Centre for Urban Sustainability and Resilience at University College London, School of Technology at University of Cambridge, Queens College Cambridge and Arup London for their financial support to the missions. The background support from the Institution of Structural Engineers (IStructE) and the committee and staff of EEFIT for the reconnaissance mission are also greatly appreciated. The authors are also grateful to the organizations and individuals whom have also helped in the missions in one way or another.

ESDM, Geological Agency-Department of Energy and Mineral Resources of Republic of Indonesia (2009). "Geological Map of Padang City." Ministry of Energy and Mineral Resources of the Republic of Indonesia. Earthquake Engineering Research Institute.

Franco, G., Stone, H., Ahmed, B., Chian, S. C., Hughes, F., Jirouskova, N., et al. (2017). "The April 162016 Mw7.8 Muisne earthquake in Ecuador - Preliminary observations from the EEFIT reconnaissance mission of May 24 - June 7," in 16th World Conference on Earthquake Engineering (Santiago), Paper No. 4982.

Goda, K., Pomonis, A., Chian, S. C., Offord, M., Saito, K., and Sammonds, P. (2012). Ground motion characteristics and shaking damage of the 11th March 2011 Mw9.0 Tohoku Earthquake. Bull. Earthquake Eng. 11, 141-170. doi: 10.1007/s10518-012-9371-x

Government of Japan (2011). 22 July 2011 - Reconstruction of Quake-hit Areas Could Cost Gov't 23 th Yen. Available online at: http://mdn.mainichi.jp/ mdnnews/news/20110722p2g00m0dm023000c (accessed January 02, 2012).

International Federation of Red Cross and Red Crescent Societies (2016). "Six Months Report Ecuador: Earthquake", ReliefWeb Website. Available online at: https://reliefweb.int/sites/reliefweb.int/files/resources/MDREC0126m.docx. pdf (accessed January 15, 2019).

Japan Meteorological Agency (JMA) (2013). Map of 2011 Tohoku (Sendai) Earthquake Observed Tsunami Heights in Japan. Available online at: https:// commons.wikimedia.org/wiki/File:Tsunami_map_Tohoku2011.svg (accessed January 15, 2019).

Kaminski, S. (2013). Engineered bamboo houses for low-income communities in Latin America. Struct. Eng. 91, 14-23.

Midorikawa, M., Iiba, M., and Koshika, N. (2004). Seismic performance evaluation of seismically isolated buildings introduced to the building code of Japan. J. Press. Vessel Technol. 126, 18-24. doi: 10.1115/1.16 38390

Ministry of Land Infrastructure Transport and Tourism (2011). Great East Japan Earthquake [In Japanese]. Available online at: http://www.mlit.go.jp/common/ 000139083.pdf (accessed January 02, 2012).

Nakamura, Y. (1989). Method for dynamic characteristics estimation of subsurface using microtremoron the ground surface. Quart. Rep. RTRI. 30, 25-33.

National Police Agency of Japan (2012). Damage Situation and Police Countermeasure. Available online at: http://www.npa.go.jp/archive/keibi/biki/ higaijokyo_e.pdf (accessed December 02, 2012).

Norma Ecuatoriana de la Construcción (2015). Ecuadorian Building Code, Seismic Loads, Earthquake-resistant Design, Ministry of Urban Development and Housing, Quito: Norma Ecuatoriana de la Construcción.

Parra, H., Benito, M. B., and Gaspar-Escribano, J. M. (2016). Seismic hazard assessment in continental Ecuador. Bull. Earthquake Eng. 14, 2129-2159. doi: 10.1007/s10518-016-9906-7

Pomonis, A., Kappos, A., Karababa, F., and Panagopoulos, G. (2011). "Seismic vulnerability and collapse probability assessment of buildings in Greece," In Human Casualties in Earthquakes: Progress in Modelling and Mitigation (Advances in Natural and Technological Hazards Research) eds R. Spence, E. So, and C. Scawthorn (London: Springer). 
Smith, B., and Sandwell, D. (2003). Accuracy and resolution of shuttle radar topography mission data. Geophys. Res. Lett. 30:1467. doi: $10.1029 / 2002$ GL016643

Standar Nasional Indonesia (2002). Tata Cara Perencanaan Ketahanan Gempa Untuk Rumah dan Gedung. Jakarta: SNI-1726-2002.

Tachikawa, T., Kaku, M., Iwasaki, A., Gesch, D., Oimoen, M., Zhang, Z., et al. (2011). ASTER Global Digital Elevation Model Version 2 - Summary of Validation Results. NASA Land Process Distributed Active Archive Center and the Joint Japan-US ASTER Science Team. Available online at: https:// ssl.jspacesystems.or.jp/ersdac/GDEM/ver2Validation/Summary_GDEM2_ validation_report_final.pdf (accessed January 15, 2019).

Uniform Building Code (1997). International Conference of Building Officials. Whittier, CA: Uniform Building Code.

UNITAR-UNOSAT (2016). Preliminary Satellite Based Damage Assessment Report 29 April 2016. Geneva: UNITAR.

United States Geological Survey (USGS) (2016). General Summary of the M7.8 Muisne Event. Reston, VA: USGS.

United States Geological Survey (USGS) (2010a). World Earthquake Report: Magnitude 7.6 - Southern Sumatra, Indonesia. Available online at: http:// earthquake.usgs.gov/earthquakes/eqinthenews/2009/us2009mebz/ (accessed January 02, 2012).

United States Geological Survey (USGS) (2010b). World Earthquake Report: Magnitude 6.6 - Southern Sumatra, Indonesia. Available online at: http:// earthquake.usgs.gov/earthquakes/recenteqsww/Quakes/us2009mfaf.php (accessed January 02, 2012).

Wilkinson, S. M., Alarcon, J. E., Mulyani, R., Whittle, J., and Chian, S. C. (2012). Observations of damage to buildings from Mw7.6 Padang earthquake of 30th September 2009. Nat. Hazards 63, 521-547. doi: 10.1007/ s11069-012-0164-y
Conflict of Interest Statement: The authors declare that this study received funding from the Engineering and Physical Sciences Research Council (EPSRC) [Grant No.: EP/H043616/1, EP/I01778X/1, and EP/P025951/1], AIR Worldwide, Cambridge Architectural Research Ltd, Global Earthquake Model, Institution of Civil Engineers (QUEST Travel Award), Sasakawa Foundation, Sellafield Ltd., Willis Research Network, Guy Carpenter, Centre for Urban Sustainability and Resilience at University College London, School of Technology at University of Cambridge, Queens College Cambridge and Arup London. The funders supported the travel costs related to the post-event reconnaissance.

At the time of writing this paper, JW was employed by Magnusson Klemencic Associates. JA was employed by Willis Re, AP and KS were employed by Cambridge Architectural Research Ltd. SF was employed by Fraser Disaster Risk Consulting. MO was employed by Sellafield Ltd. GF was employed by Guy Carpenter. SK and JL were employed by Arup London.

The remaining authors declare that the research was conducted in the absence of any commercial or financial relationships that could be construed as a potential conflict of interest.

Copyright (c) 2019 Chian, Wilkinson, Whittle, Mulyani, Alarcon, Pomonis, Saito, Fraser, Goda, Macabuag, Offord, Hunt-Raby, Sammonds, Franco, Stone, Ahmed, Hughes, Jirouskova, Kaminski and Lopez. This is an open-access article distributed under the terms of the Creative Commons Attribution License (CC BY). The use, distribution or reproduction in other forums is permitted, provided the original author(s) and the copyright owner(s) are credited and that the original publication in this journal is cited, in accordance with accepted academic practice. No use, distribution or reproduction is permitted which does not comply with these terms. 